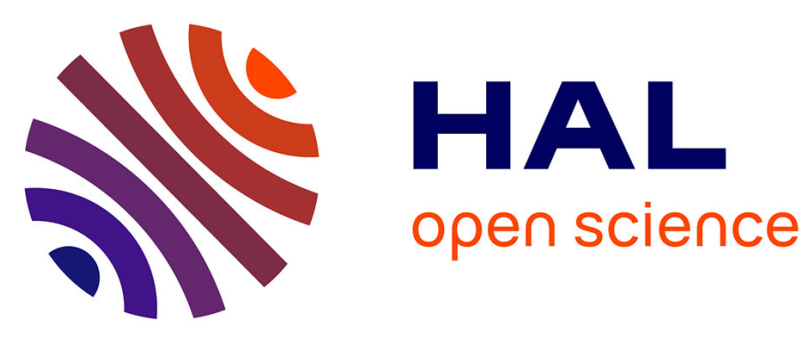

\title{
Antimalarial Bicyclic Peroxides Belonging to the G-Factor Family: Mechanistic Aspects of their Formation and Iron (II) Induced Reduction
}

Jérémy Ruiz, Joëlle Azéma, Corinne Payrastre, Michel Baltas, Beátrice Tuccio, Henri Vial, Christiane André-Barrès

\section{To cite this version:}

Jérémy Ruiz, Joëlle Azéma, Corinne Payrastre, Michel Baltas, Beátrice Tuccio, et al.. Antimalarial Bicyclic Peroxides Belonging to the G-Factor Family: Mechanistic Aspects of their Formation and Iron (II) Induced Reduction. Current Topics in Medicinal Chemistry, 2014, 14 (14), pp.1668-1683. 10.2174/1568026614666140808154326 . hal-02322051

\section{HAL Id: hal-02322051 \\ https://hal.science/hal-02322051}

Submitted on 21 Oct 2019

HAL is a multi-disciplinary open access archive for the deposit and dissemination of scientific research documents, whether they are published or not. The documents may come from teaching and research institutions in France or abroad, or from public or private research centers.
L'archive ouverte pluridisciplinaire HAL, est destinée au dépôt et à la diffusion de documents scientifiques de niveau recherche, publiés ou non, émanant des établissements d'enseignement et de recherche français ou étrangers, des laboratoires publics ou privés. 


\title{
Antimalarial bicyclic peroxides belonging to the G-factor family: mechanistic aspects of their formation and iron (II) induced reduction.
}

\author{
Jérémy Ruiz, ${ }^{\mathrm{a}}$ Joëlle Azéma, ${ }^{\mathrm{a}}$ Corinne Payrastre, ${ }^{\mathrm{a}}$ Michel Baltas, ${ }^{\mathrm{a}}$ Béatrice Tuccio, ${ }^{\mathrm{b}}$ Henri Vial,,${ }^{\mathrm{c}}$ Christiane André-Barrès. ${ }^{\mathrm{a}^{*}}$
}

${ }^{a}$ Laboratoire de Synthèse et de Physicochimie de Molécules d'Intérêt Biologique, UMR CNRS 5068, Université Paul-Sabatier, 118 route de Narbonne, F-31062 Toulouse cedex 04, France.

${ }^{b}$ Institut de Chimie Radicalaire, UMR AMU-CNRS 7273, Laboratoire Chimie Provence, Equipe SACS, Aix-Marseille Université -CNRS UMR 6264, case 512, Campus de Saint Jérôme, 13397 Marseille cedex 20, France

${ }^{c}$ Dynamique des Interactions Membranaires Normales et Pathologiques, UMR CNRS 5235, Université Montpellier 2, Place E. Bataillon, F-34095 Montpellier cedex 5, France.

Corresponding author E-mail: candre@ chimie.ups-tlse.fr

\begin{abstract}
Artemisinin and its derivatives are peroxide-containing compounds targeting $P$. falciparum. We review here structural analogues of bicyclic peroxides belonging to the $\mathrm{G}$ factors family presenting antimalarial properties. They were synthesised under Mannich type conditions, followed by an autoxidation step resulting exclusively in the peroxide. As the electron transfer from haem or free iron to the peroxide is the first step in the mode of action of artemisinin-like compounds, the redox properties of some endoperoxides were studied by electrochemistry allowing the evaluation of the reduction standard potentials. The $\mathrm{Fe}(\mathrm{II})$ induced reduction was also investigated and the reactivity of the C-centered radical intermediate formed was linked to the antimalarial activity. These bicyclic peroxides both with various hybrid molecules containing the endoperoxide framework were evaluated in vitro against Plasmodium falciparum. They exhibited moderate to good activities.
\end{abstract}

Keywords: malaria, cyclic peroxide, C-centered radical, hybrid molecules.

\section{Table of contents}

1. Introduction

2. Synthesis of endoperoxides via spontaneous oxygen uptake

3. Crucial role of the peroxyhemiketal function

4. Dissociative electron transfer studies

5. $\mathrm{Fe}(\mathrm{II})$-induced Reduction

6. Structural variations of the G-factors. 6.1 Modifications on the lateral chain $6.2 \alpha$-Spiro-endoperoxides synthesis

6.3 Hybrid molecules

6.3.1 Streptocyanine-endoperoxide

6.3.2 Ciprofloxacin-endoperoxide

6.3.3 4-Aminoquinoline-endoperoxide

Conclusion 


\section{Introduction}

Malaria caused by protozoan parasites of the genus Plasmodium is the most prevalent parasitic disease with approximately $50 \%$ of the world's population at risk, mainly in many tropical and subtropical regions, with an estimate of 216 million cases of malaria and 655,000 deaths worldwide annually[1]. Four species of Plasmodium, P. falciparum, P. vivax, P. ovale and P. malariae commonly infect humans, and a fifth, $P$. knowlesi, has recently been identified as being responsible for a significant number of human cases in South-East Asia. [2]

Malaria remains a major world health problem following the emergence and spread of $P$. falciparum, the most dangerous of the Plasmodium parasites that infect and is resistant to the majority of antimalarial drugs.[3] The discovery of the sesquiterpene lactone artemisinin (known as Qing hao su) in 1972 by Chinese scientists and the subsequent development of potent derivatives have been a key event in the malaria treatment because the artemisinins rapidly kill all the blood stages of the parasite, resulting in the shortest fever clearances times of all antimalarials. Artemisinin-based combination therapies (ACTs) which combine a potent but short-lived artemisinin derivative such as artesunate, artemether or dihydroartemisinin with a longer-lasting partner drug are now the first-line recommendation for $P$. falciparum malaria in most endemic areas and are increasingly used against the chloroquine-resistant $P$. vivax malaria problem [4].

Since the discovery of artemisinin, the search for new generation of artemisinin-based therapeutics has been intensively pursued resulting in new classes of peroxide-containing compounds such as 1,2,4-trioxane,[5-9] 1,2,4-trioxolanes[10,11], 1,2,4,5-teraoxanes[12], cyclic peroxyketal[13] and endoperoxides[14-16] targeting $P$. falciparum.

For the chemical synthesis of these peroxide-containing compounds, several oxygen sources were used in order to introduce the O-O bond such as: hydrogen peroxide, ozone, singlet oxygen, and to a less extent molecular oxygen.

Hydrogen peroxide was thus added to carbonyl compounds or to epoxide leading respectively to gem-dihydroperoxides or to hydroperoxyhemiketals[17] and to $\beta$-hydroxy-hydroperoxides[18] which were precursors of several cyclic peroxides such as 1,2,4,5-tetraoxanes,[19,20] 1,2-dioxolanes,[21] 1,2,4-trioxanes[22] or 1,2-dioxanes.[23,24]

In a same way, ozone was reacted with alkenes or more generally enol ethers and oxime ethers leading to peroxycarbenium ion species[25] which in turn were the reactive intermediates in peroxide formation as described for the synthesis of the natural compound Yingzhaosu,[26] plakinic acid A analogues[27] or various 1,2,4-trioxanes.[28,29] In addition, Vennerstrom has shown that ozone treatment of oxime ethers and addition of the peroxycarbenium ion on ketones, led to 1,2,4-trioxolanes which revealed to be promising antimalarial candidates.[30] The fully synthetic 1,2,4-trioxolane peroxide OZ439, appears as an exciting prospect demonstrating high potency and longer plasma exposure compared to artemisinin [31]. This compound offers new hope for a single-dose cure of uncomplicated malaria and is currently into phase 2 trials supported by medicine for Malaria Venture [32].

Singlet oxygen was also used as a source of oxygen to access peroxide derivatives via the Schenck reaction or [4+2] or $[2+2]$ cycloadditions. Arteflene[9] was synthesized using the Schenck reaction. Singh[33] and Bloodworth[34,35] independently synthesized trioxanes by photooxygenation of allylic alcohols or olefins followed by acid-catalyzed condensation of carbonyl compounds on hydroperoxides. Singlet oxygen [4+2] cycloaddition on cyclopentadiene was developed by Jefford[36] during Fenozan (BO7) synthesis. This methodology was reinvestigated by Meunier in the synthesis of trioxaquines. [37] Jefford et al.[38] have also shown that singlet oxygen reacts through a [2+2] cycloaddition on enol ethers yielding the 1,2-dioxetane intermediates, which, at low temperature and acid catalysis react on ketones to give the desired 1,2,4-trioxanes. Posner[39] modified this method, by using thio enol ethers instead of enol ethers to prepare sulfone trioxanes.

Molecular oxygen was scarcely used as its reactivity is low. Interestingly however, it could be used in the preparation of 3hydroxy-1,2-dioxanes. O'Neill et al.[40] optimized a route to spirotrioxanes via the Co(II) catalyzed preparation of triethylsilyl peroxides. Posner and Bachi[41] perfected a radical process called TOCO (Thiol-Olefine Co-Oxygenation) giving access to dioxanes or trioxanes via formation of a peroxyl radical intermediate. O'Neill reinvestigated this process[42] by describing a 1,2,4-trioxane synthesis. Posner et al.[43] synthesized cyclic peroxyketals by using the Snider and Shi protocol,[44] e.g. photoenolisation followed by oxygenation. Blaumstark et al.[45] described the synthesis of pentasubstituted 3-hydroxy-1,2-dioxolanes via $\mathrm{O}_{2}$ trapping of intermediates generated during the thermolysis of cyclic $\alpha$ azo hydroperoxides.

The mode of action of those antimalarial peroxides prodrugs is based on Fe(II) activation causing oxygen-oxygen bond breaking; the oxy radical intermediate undergoes rearrangement furnishing primary or secondary carbon-centered radical. These highly reactive intermediates are thought to cause irreversible damage to certain parasite's biomolecules.[46] They trigger damage to 
cellular lipids and digestive vacuole membranes, inactivation of Plasmodium proteins, alkylation of haem and interference with haem sequestration into crystals and finally parasite death. The effect on intraerythrocytic stages is broad, including strong action on rings stages as well as trophozoits and early schizonts.

Our lab is interested in new types of antimalarial agents potentially acting as artemisinin. We focused our efforts on the syntheses of new endoperoxides, related to the phytohormones known as $\mathrm{G}$ factors $(\mathbf{G 1}, \mathbf{G 2}, \mathbf{G 3})$ which are natural compounds extracted from leaves of Eucalyptus grandis (Figure 1). These factors act as growth regulators and are abundant in leaves after a frost period or hydric stress. They cannot be present in their physiological forms, but rather in some inactive form, and are readily released in response to damage to the plant or to a biological stimulus.[47] They constitute a family of six-membered unsaturated cyclic endoperoxides fused to another six-carbon ring derived from syncarpic acid.

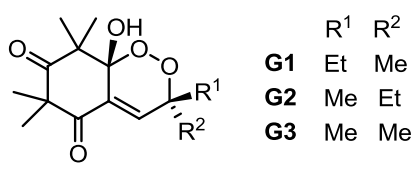

Figure 1 Natural G-Factors : G1, G2, G3.

The present work reviews our synthetic program on the construction of bicyclic endoperoxides belonging to the G-factor family and our mechanistic studies which aimed at elucidating their mode of action. On the basis of this analysis, new structures and hybrid molecules are presented in order to pave the way for new type of antimalarial endoperoxides.

\section{Synthesis of endoperoxides via spontaneous oxygen uptake}

First, we developed a straightforward synthesis of endoperoxides belonging to the G-factor series. This synthesis is based on two key-steps: formation of a Mannich base as described by Bolte [48] followed by autoxidation (Scheme 1). Mannich bases were formed from reaction between syncarpic acid and an iminium issued from the reaction of different aldehydes with piperidine. Preparation of Mannich bases intermediates allows minimizing or avoiding the formation of Michael bis-adduct. Ethylenic ketones were then easily released under acidic conditions. Depending on the substituents, equilibrium between enone and dienol can take place. [49]
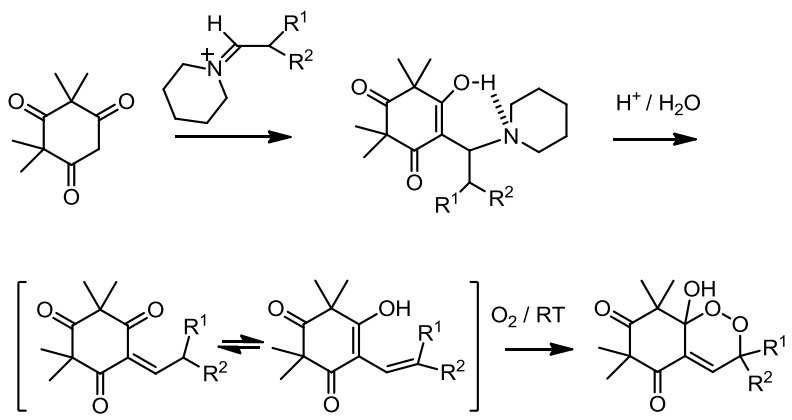

Scheme 1: Synthesis of the endoperoxide frame.

The addition of the molecular dioxygen occured more or less rapidly, depending on the substituents of the dienols, affording the corresponding endoperoxides.

This quite surprising autoxidation operates in absence of any sensitizer, even in the dark and without solvent or any solvent excepted hydroxylated ones. Molecular dioxygen, in its fundamental triplet state has been shown to be trapped by the dienol system, singlet dioxygen being not implied. In fact, the presence of DABCO, a well-known singlet quencher, didn't inhibit the autoxidation.

On the contrary, as tert-butyl mercaptan in catalytic amount was found to inhibit the reaction, we investigated this autoxidation by spin trapping / EPR technique. 
The spontaneous addition of dioxygen on 1a was followed by spin trapping (ST) combined with EPR spectroscopy and mass spectrometry (MS).[50] Two different nitrones, i.e. the commercially available 4- $\{(E)$-[tert-butyl(oxido)imino]methyl $\}$ pyridine 1 oxide (POBN), and the ${ }^{31} \mathrm{P}$-labelled trinitrone diethyl $\{1-[(Z)-(3,5$-bis $\{(E)-[1$ (diethoxyphosphoryl)-1-methylethyl] (oxido) imino] methyl\}-benzylidene)(oxido)amino]-1-methylethyl/phosphonate (TN), were used to trap the radical intermediates formed during the autoxidation. The EPR spectra of TN-spin adducts provide more information about the addend structure because the strong hyperfine coupling constant with the phosphorus nucleus $\left(a_{\mathrm{P}}\right)$ is usually very sensitive to the nature of the radical trapped. Whatever the nitrone, a single mono-radical nitroxide, i.e. a carbon-centered radical spin adduct, was EPR detected. Similar experiments were performed with two ${ }^{13} \mathrm{C}$-labelled precursors $\mathbf{1 b}$ and $\mathbf{1 c}$, obtained from labelled syncarpic acid on two different and crucial positions, which allowed us to identify precisely the radical center in the addend. Actually, identical EPR spectra were obtained for $\mathbf{1 a}$ and $\mathbf{1 b}$, while an extra coupling with the ${ }^{13} \mathrm{C}$ nucleus was EPR-observed in the case of $\mathbf{1 c}\left(a_{13 \mathrm{C}}=1.14 \mathrm{mT}\right)$, as shown in Scheme 2. The hyperfine coupling constants obtained for the POBN-C spin adduct with 1a and $\mathbf{1 b}$ were $a_{\mathrm{N}}=1.64 \mathrm{mT}$, $a_{\mathrm{H}}=0.16 \mathrm{mT}$ and with $1 \mathrm{c} a_{\mathrm{N}}=1.64 \mathrm{mT}, a_{\mathrm{H}}=0.16 \mathrm{mT}$ and $a_{13 \mathrm{C}}=1.14 \mathrm{mT}$. Similarly, the hyperfine coupling constants obtained for the TN-C spin adduct with 1a and $1 \mathbf{b}$ were $a_{\mathrm{N}}=1.55 \mathrm{mT}, a_{\mathrm{H}}=0.19 \mathrm{mT}$ and with $1 \mathrm{c} a_{\mathrm{N}}=1.55 \mathrm{mT}, a_{\mathrm{H}}=0.19 \mathrm{mT}$ and $a_{13 \mathrm{C}}=$ $1.14 \mathrm{mT}$.

In order to define more precisely the spin adduct structures, the ST/MS technique was then employed without preliminary chromatographic separation. The diamagnetic hydroxylamine derivatives of the spin adduct were detected by electrospray ionization mass spectrometry (ESI-MS), in both positive and negative modes, and their structures were elucidated by tandem mass spectrometry (MS/MS).
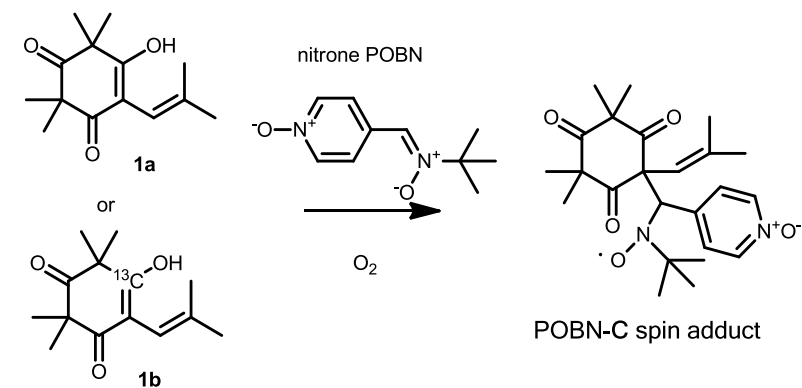

POBN-C spin adduct two POBN adducts showing the same EPR spectrum
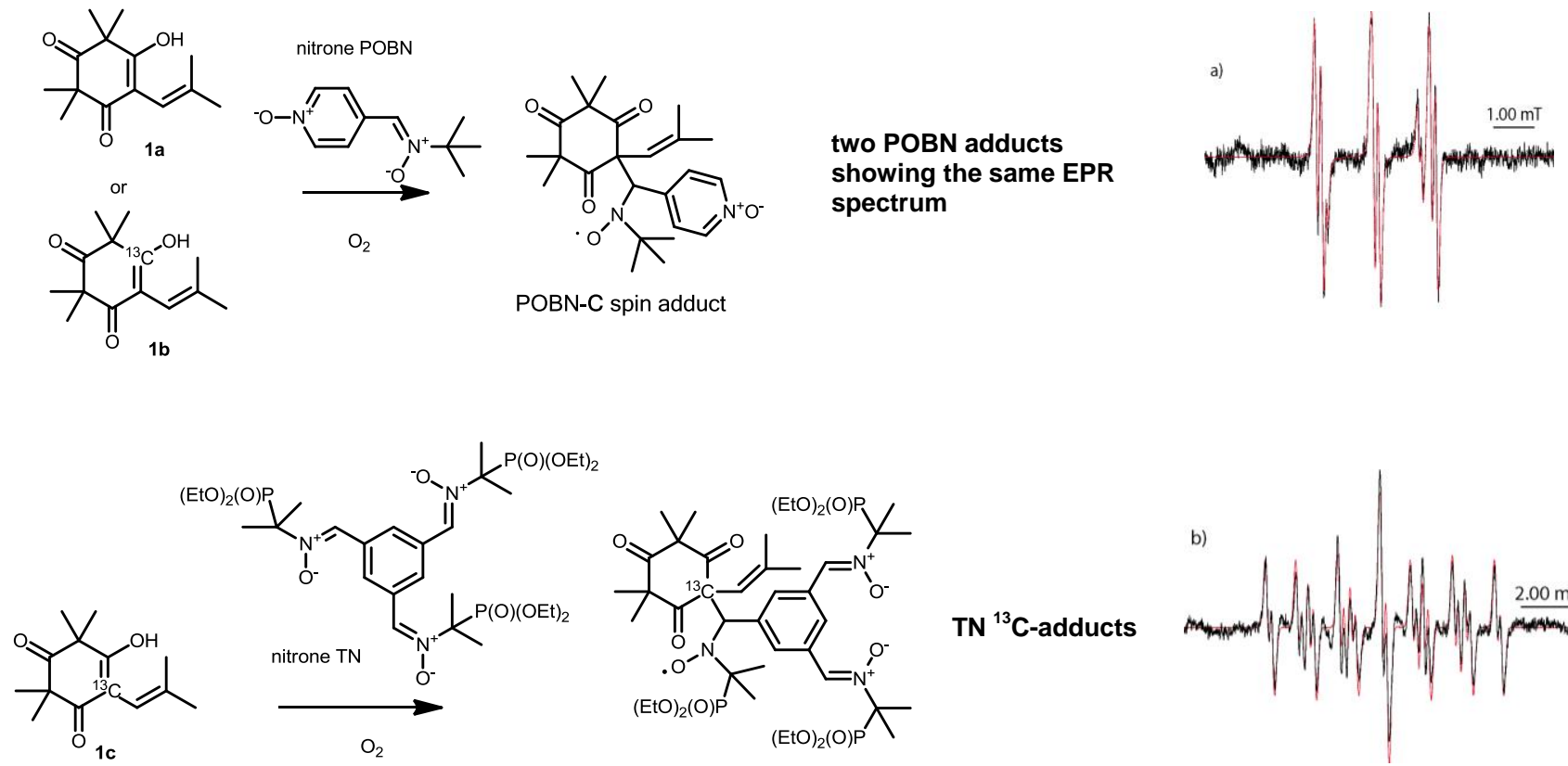

TN ${ }^{13} \mathrm{C}$-adducts

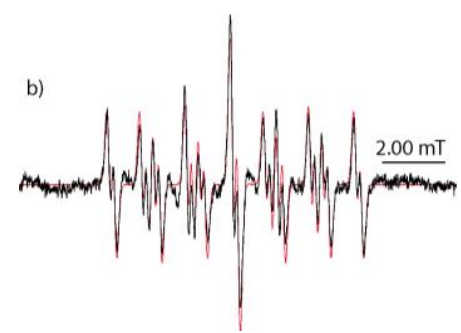

Scheme 2: Experimental EPR signals (black full lines) and superimposed simulations (red dotted lines) obtained in deoxygenated benzene after $1 \mathrm{~h}$ of reaction between molecular oxygen and (a) $1 \mathbf{a}$ or $\mathbf{1 b}\left(0.2 \mathrm{~mol} \mathrm{dm}^{-3}\right)$ in the presence of POBN $\left(0.2 \mathrm{~mol} \mathrm{dm}^{-3}\right)$, and (b) $1 \mathbf{c}\left(0.2 \mathrm{~mol} \mathrm{dm} \mathrm{dm}^{-3}\right)$ in the presence of $\mathrm{TN}\left(0.1 \mathrm{~mol} \mathrm{dm}^{-3}\right)$. The simulations led to the following hyperfine coupling constant values: a) $\left.a_{\mathrm{N}}=1.64 \mathrm{mT}, a_{\mathrm{H}}=0.16 \mathrm{mT} ; \mathrm{b}\right) a_{\mathrm{N}}=1.55 \mathrm{mT}, a_{\mathrm{H}}=0.19$ $\mathrm{mT}, a_{\mathrm{P}}=4.26 \mathrm{mT}$ and $\left.a_{13 \mathrm{C}}=1.14 \mathrm{mT}\right)$.

Following this ST/EPR/MS study, the mechanism pathway presented in Scheme 3 was proposed for this oxidation. The results obtained are consistent with the pathway $\mathbf{B}$ but this does not mean that the pathway A could not occur simultaneously. Under the experimental conditions considered here, the biradical formed from 1a in pathway $\mathbf{B}$ was unambiguously identified. However, the ring closure into the biradical formed in pathway A could be much faster than the trapping reaction. Thus, pathway $\mathbf{A}$ could not be dismissed as an alternative or even as a main process. Whatever it may be, this ST/EPR/MS study clearly demonstrates that the autoxidation corresponds to a radical process. 


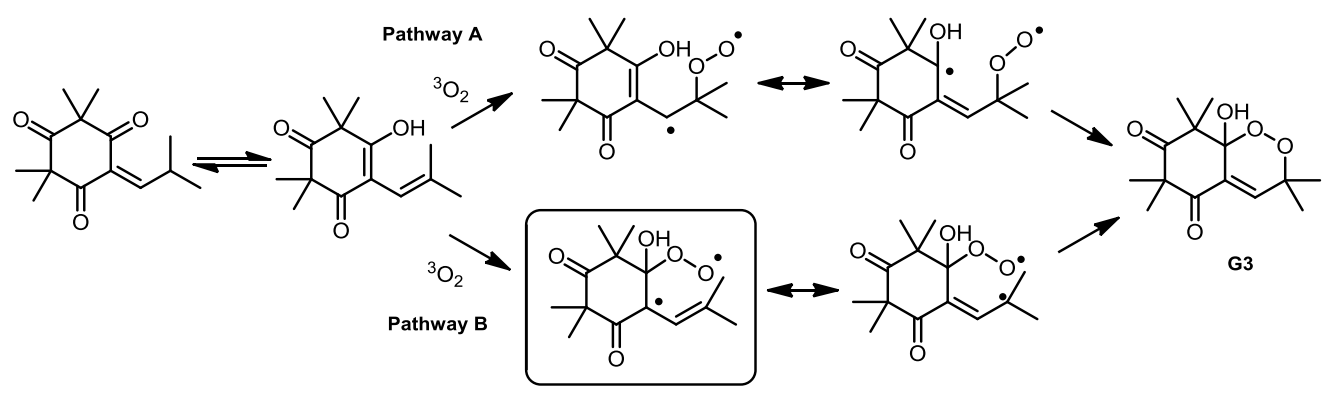

Scheme 3: Proposal for triplet biradical intermediates formation during the autoxidation step.

\section{Crucial role of the peroxyhemiketal function}

Based on the synthetic methodology described above, several compounds were prepared by varying the aldehyde used in the Mannich based preparation. After elimination of the piperidine and oxygen uptake, several endoperoxides were alkylated or benzylated on the peroxyhemiketal position in order to mimic trioxane. The compounds were evaluated against both chloroquine susceptible (Nigerian and 3D7) and resistant (FcM29 and W2) P. falciparum strains, the results are presented in Table 1.[51-53] The natural compound $\mathbf{G 3}(\mathrm{R}=\mathrm{OH})(\mathbf{2})$ possess a mild activity $(36 \mu \mathrm{M})$ on Nigerian $P$. falciparum strain and appears similarly active against resistant strains. Remarkably, methylation of the peroxyhemiketal function yielded $\mathbf{G 3 M e}(\mathrm{R}=\mathrm{OMe})(\mathbf{3})$ derivative which appears 100 fold more active on the same strain with $\mathrm{IC}_{50}$ of $0.28 \mu \mathrm{M}$. Fluorination of this position gave an inactive compound (4). The extension of the alkyl chain did not change the activity as compounds $\mathbf{5 , 6}$ and $\mathbf{7}$, showed similar activities to G3Me. Finally, the benzylation yielded endoperoxide 8 which exhibited among the highest activities $\left(\mathrm{IC}_{50}=0.37\right.$ and $0.10 \mu \mathrm{M}$ on chloroquine sensitive and resistant strains of Plasmodium falciparum, respectively). The enantiomers were separated by chiral column chromatography, both enantiomers displayed similar activity. This last result is a clue to rule out the hypothesis of an enzymatic target in the mode of action.

Table 1 In vitro antimalarial activity on different strains. Antiplasmodial activity was evaluated after contact with the different strains of $P$. falciparum for $48 \mathrm{~h}$ (duration of the erythrocyte cycle), and is expressed as $\mathrm{IC}_{50}$ which is the concentration that inhibit by $50 \%$ the growth of the parasite.

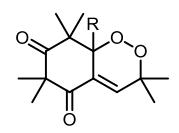

$\operatorname{IC}_{50}(\mu \mathrm{M})^{a}$ for the various strains

\begin{tabular}{|c|c|c|c|c|c|}
\hline $\mathbf{R}$ & & Nigerian & 3D7 & FcM29 & W2 \\
\hline $\mathbf{O H}$ & 2 & 36 & 62 & 41 & 38.5 \\
\hline $\mathrm{OCH}_{3}$ & 3 & 0.28 & 0.40 & 0.23 & 0.14 \\
\hline $\mathbf{F}$ & 4 & $>100$ & - & - & - \\
\hline $\mathrm{O}\left(\mathrm{CH}_{2}\right)_{2} \mathrm{CH}_{3}$ & 5 & 0.16 & - & - & - \\
\hline $\mathrm{O}\left(\mathrm{CH}_{2}\right)_{3} \mathrm{CH}_{3}$ & 6 & 0.76 & 1.04 & 0.19 & 0.44 \\
\hline $\mathrm{O}\left(\mathrm{CH}_{2}\right)_{7} \mathrm{CH}_{3}$ & 7 & 0.18 & - & - & - \\
\hline $\mathrm{OCH}_{2} \mathrm{C}_{6} \mathrm{H}_{5}$ & 8 & 0.21 & 0.37 & 0.10 & 0.20 \\
\hline (+) $\mathrm{OCH}_{2} \mathrm{C}_{6} \mathrm{H}_{5}$ & (+) 8 & 0.36 & - & - & - \\
\hline (-) $\mathrm{OCH}_{2} \mathrm{C}_{6} \mathrm{H}_{5}$ & (-) 8 & 0.34 & - & - & - \\
\hline $\mathrm{O}-\mathrm{CH}_{2} \mathrm{C}_{5} \mathrm{H}_{4} \mathrm{~N}$ & 9 & 0.28 & 0.82 & 0.12 & 0.33 \\
\hline Artemisinin & & 0.008 & 0.019 & 0.004 & 0.004 \\
\hline Chloroquin & & 0.03 & 0.019 & 0.155 & 0.125 \\
\hline
\end{tabular}

${ }^{a} \mathrm{IC}_{50}$ values are duplicated and were considered acceptable when values did not vary by more than a factor of 2.5 to3.

This work demonstrates that alkylation of the peroxyhemiketal function is crucial for antiplasmodial activity and that antimalarial activity of this type of endoperoxide is quite substantial with $\mathrm{IC}_{50}$ below $1 \mu \mathrm{M}$. 
Activities of endoperoxides are always related to $\mathrm{O}-\mathrm{O}$ bond cleavage induced by iron(II) activation. In this context we decided to study and compare the reduction of the G3 and G3Me both by electrochemistry and by iron(II) induced degradation.

\section{Dissociative electron transfer studies}

As the first step in the mode of action of artemisinin-like compounds has been shown to be a dissociative electron transfer from the iron(II) of the haem to the peroxidic bond,[54-56] we focused our efforts in determining the reductions potentials of our endoperoxides G3 (2) and G3Me (3) in the aim to compare them to each other and to artemisinin.

The reduction was thus studied by cyclic voltammetry and convolution analysis.[57] One electron was detected during the reduction of both compounds and a slow and irreversible system was observed. Electron transfer led to irreversible cleavage of the O-O bond. Detailed analysis of the voltammetry curves using Marcus theory, revealed a non-linear dependence on the transfer coefficient indicating a change from a stepwise mechanism to one with more concerted character with increasing potential (Figure 2). In the concerted mechanism, the electron is accepted into the $\sigma^{*}$ orbital, largely associated with the O-O bond, resulting in simultaneous cleavage to generate a distonic radical anion 'ORRO'. There is also the possibility of a stepwise dissociative mechanism when there is an energetically accessible $\pi^{*}$ orbital within the molecule. In the stepwise mechanism, the initial electron transfer results in the formation of an intermediate radical anion, followed in a second step, by cleavage of the O-O bond $\left(k_{\text {frag }}\right)$, giving then the radical anion.

The O-O bond dissociation energies, estimated by quantum calculations using density functional theory (DFT), from the difference between the total energy of the most stable form for each molecule in its singlet and triplet state at the B3LYP 6-31G* level, were taken into account in the experimental data when evaluating the standard reduction potentials and other pertinent thermochemical informations such as reorganization energy and activation energy. The values of the standard reduction potentials of the stepwise mechanism $\left(E_{s t}^{\circ}\right)$ for both $\mathbf{G 3}$ and G3Me were estimated at respectively -1.70 and $-1.64 \mathrm{~V}$, very close to the values of the peak potentials $(-1.67$ and $-1.61 \mathrm{~V}$ at the rate of $2 \mathrm{~V} / \mathrm{s})$. The values of the standard reduction potentials of the concerted mechanism $\left(E_{c}^{\circ}\right)$ were about -0.82 and $-0.84 \mathrm{~V}$ close to the value of artemisinin standard reduction potential $(-0.89 \mathrm{~V})$ for which only a purely concerted mechanism is present.

Using density functional theory (DFT) with B3LYP hybrid functional and 6-311+G(d,p) basis set, [58] the reaction pathway of the electron transfer was also carried out. The stationary points and related energy differences were determined. Both for G3 and G3Me, the formation of two intermediate radical anions (A and B, Figure 2 a) resulting from the electron transfer, were found and characterized, along with the localization of the transition states associated with the reaction pathway. The fact that two intermediate radical anions may be characterized is proper to a stepwise reduction mechanism.

When G3 receives an electron, it goes in the LUMO orbital ( $\pi^{*}$ character of the conjugated double bond $\mathrm{C}=\mathrm{C}-\mathrm{C}=\mathrm{O}$ ). The spin densities on the radical anion A show that the unpaired electron is delocalized on the $\mathrm{C}=\mathrm{C}-\mathrm{C}=\mathrm{O}$ group and the SOMO of conformation A is on these atoms. Conformation B is $1.38 \mathrm{eV}(31.8 \mathrm{kcal} / \mathrm{mol})$ lower in energy. It is the thermodynamic product. There is an extra electron on the $\alpha$ energy levels, and the associated orbital has a $\sigma^{*}$ character on the O-O bond. The spin densities show that the unpaired electron is located on this $\mathrm{O}-\mathrm{O}$ bond.
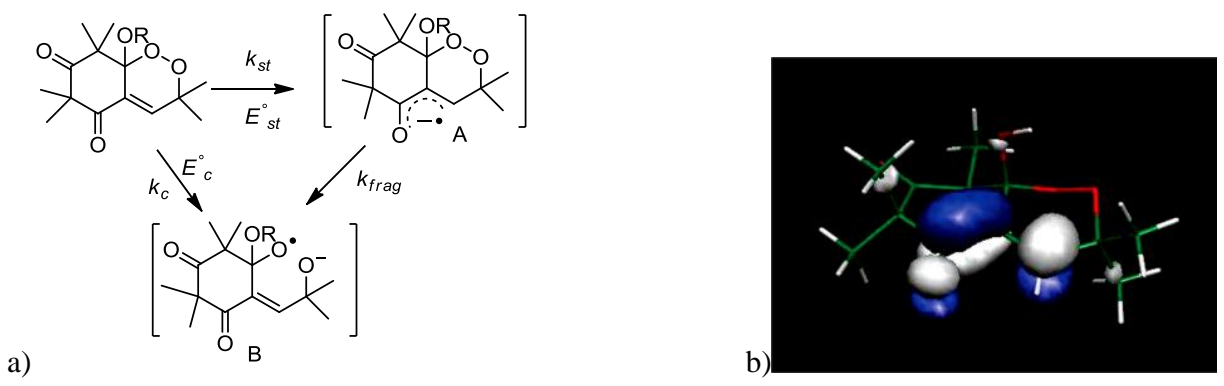

Figure 2: a) Competition between concerted and stepwise mechanism of the dissociative electron transfer, and b) LUMO of the G3.

We calculated that the neutral/anion energy gap was 1.06 and $2.44 \mathrm{eV}$ for respectively radical anion A and radical anion B resulting of the reduction of $\mathbf{G 3}$. The transition state between those two states is situated at $0.15 \mathrm{eV}(3.46 \mathrm{kcal} / \mathrm{mol})$ above A. Values were found to be quite similar for G3Me, with the neutral/anion energy gap of respectively 1.04 and $2.34 \mathrm{eV}$ for A and B. 
The occurrence of the stepwise mechanism for the electron transfer, can be explained by the presence of the more accessible LUMO of the $\mathbf{G 3}$ with a $\pi^{*}$ character (Figure $2 \mathrm{~b}$ ). Then the electron is transferred into the LUMO+1 which is situated on the O-O bond and has a $\sigma^{*}$ character, leading to the breaking $\mathrm{O}-\mathrm{O}$ bond and furnishing the second stable radical anion. The reorganization energy upon electron transfer in relation to the Marcus theory and the intrinsic activation energy were also calculated using the DFT method. The calculated values are in good agreement with their available experimental counterparts obtained from analysis of the voltammetry curves.

This interesting result does not explain the differences encountered in the biological activity of the two compounds. Indeed, they present quite similar standard potentials as artemisinin and their O-O bond dissociation energies (BDE) are in the same range. Nevertheless, this mechanism allows understanding the reason why these endoperoxides (especially G3Me) can exhibit antimalarial properties even if they present a steric hindrance of the O-O bond, hampering the approach of the haem, as the electron will first go into the $\pi^{*}$ orbital of the conjugated double bond.

\section{Fe(II)-induced Reduction}

A chemical approach to the reduction process was then undertaken.[59] We studied the Fe(II)-induced reduction of G3 $(\mathrm{R}=\mathrm{OH})$, G3Me $(\mathrm{R}=\mathrm{OMe})$ and $\mathbf{G 3 F}(\mathrm{R}=\mathrm{F})$ and then characterized the degradation products. The conditions $\left(\mathrm{FeSO} \mathrm{CH}_{4}\right.$; $\mathrm{CH}_{3}$ $\mathrm{H}_{2} \mathrm{O}: 1 / 1$ ) were chosen to be closer to biological conditions than the THF-based system. In that case $\mathrm{pH}$ medium is acidic ( $\mathrm{pH} 5$ ) mimicking the $\mathrm{pH}$ of the parasite food vacuole ( $\mathrm{pH} 4.5-5.0)$.[60]

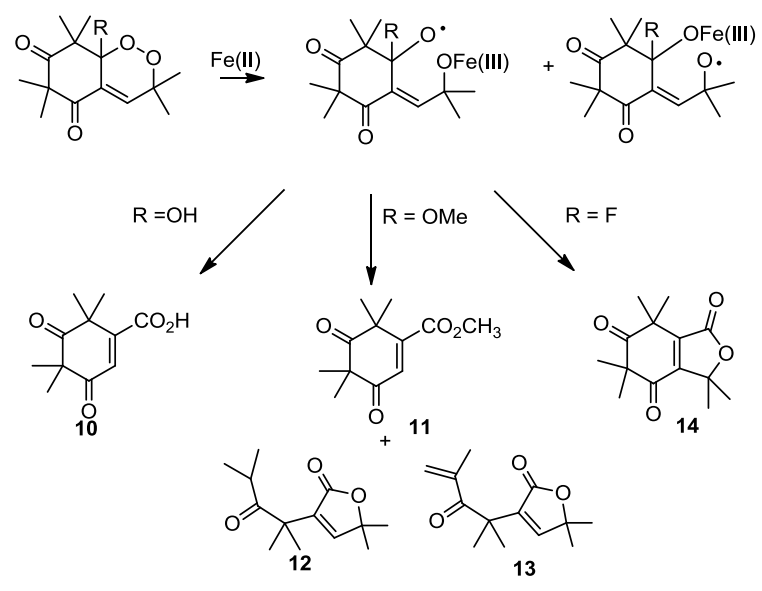

Scheme 4 : End-products issued from the Fe(II) induced reduction of G3, G3Me and G3F.

A major product 10 (Scheme 4) was obtained in 82\% yield from G3, whereas under the same conditions, three major compounds, 11, 12, and 13 (respectively, 23\%, 24\%, and 24\%), were isolated from G3Me. In both cases starting material was still present (about 5\%). One major compound $14(60 \%)$ was generated by reduction of the fluoroendoperoxide G3F.

In order to get insight in the mechanisms involved in each reduction, ${ }^{13} \mathrm{C}$-labelled derivatives for $\mathbf{G 3}$ and $\mathbf{G 3 M e}$ were synthesized from ${ }^{13} \mathrm{C}$-labelled syncarpic acid on two crucial positions ${ }^{13} \mathrm{C}_{1}$ and ${ }^{13} \mathrm{C}_{2}$. In this way, two series of endoperoxides were obtained. The first one labelled on ${ }^{13} \mathrm{C}_{6}$ was issued from ${ }^{13} \mathrm{C}_{1}$ syncarpic acid whereas the second one was issued from ${ }^{13} \mathrm{C}_{2}$ syncarpic acid and consisted in mixture $1 / 1$ of compounds labelled on ${ }^{13} \mathrm{C}_{1}$ or ${ }^{13} \mathrm{C}_{7}$. The analysis of the ${ }^{13} \mathrm{C}$-labelled distribution and studies of multiplicity obtained with coupling of ${ }^{1} \mathrm{H}$ - and ${ }^{13} \mathrm{C}$ allowed elucidation of the mechanisms involved (Schemes 5 and 6 ). 
a)

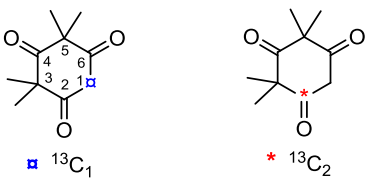

b)
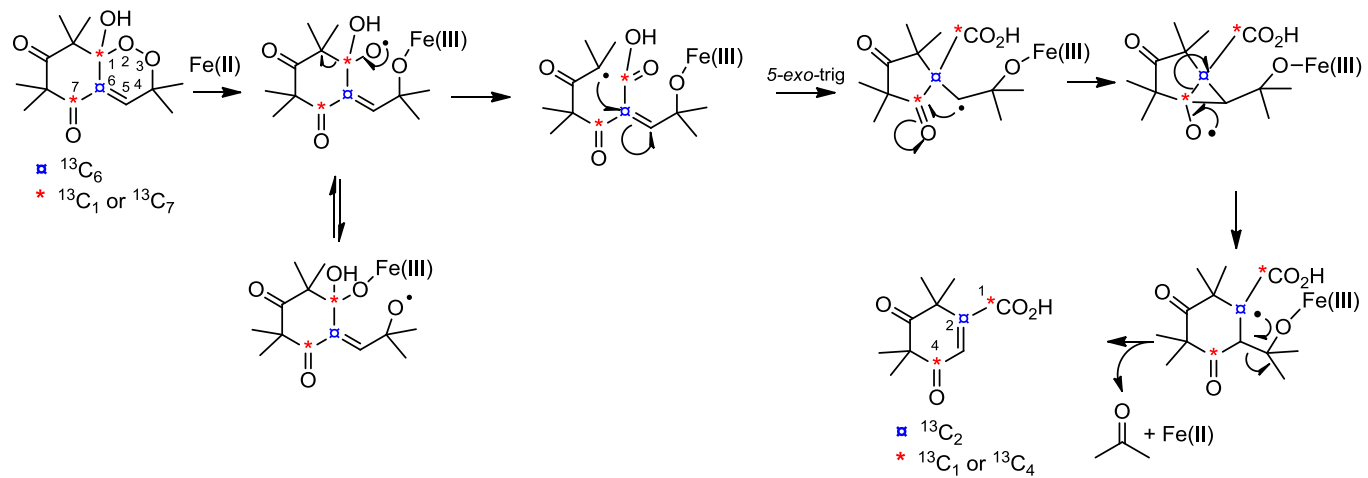

Scheme 5 : a) ${ }^{13} \mathrm{C}$ labelled syncarpic acid on position 1 and 2. b) Proposal for the $\mathrm{Fe}(\mathrm{II})$-induced reduction of labelled $\mathbf{G 3}$.

In the case of the $\mathbf{G 3}$, transfer of a single electron from $\mathrm{Fe}(\mathrm{II})$ to the $\mathrm{O}-\mathrm{O}$ bond is followed by the homolytic cleavage of the peroxidic linkage affording only products issued from the $\mathrm{O}^{1}$-centered radical. Thus, the $\mathrm{O}^{1}$ centered radical quickly evolves to tertiary gem dimethyl C-centered radical (Scheme 5). This tertiary radical rearranged within 5-exo-trig cyclisation, and after ring expansion and loss of acetone and iron(II), acid $\mathbf{1 0}$ is obtained.

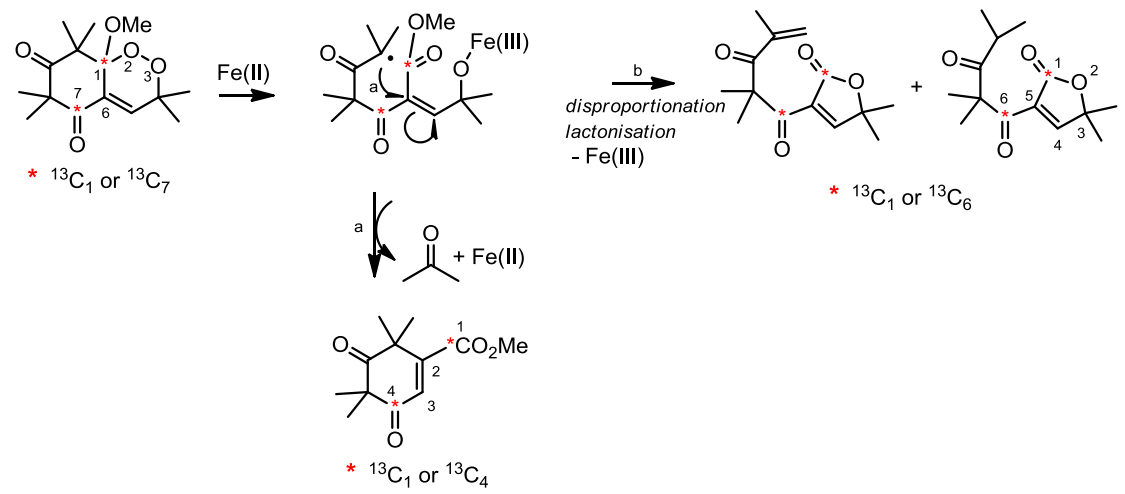

Scheme 6: Proposal of mechanism of $\mathrm{Fe}(\mathrm{II})$ induced reduction of ${ }^{13} \mathrm{C}$ labelled G3Me.

In the case of G3Me, the tertiary radical evolves following two different pathways (Scheme 6). In pathway (a) a mechanism analogue to the one involved in G3 reduction was observed leading to the methyl ester $\mathbf{1 1}$ whereas in pathway (b) disproportionation and lactonisation with concomitant elimination of Fe(III), occurred affording compounds 12 and 13.

In the case of G3F, only the lactone $\mathbf{1 4}$ was obtained (Scheme 7); its formation is likely due to the formation of the tertiary gem dimethyl C-centered radical which quickly rearranges (5-exo-trig cyclisation, addition on the carbonyl and ring expansion) and then to the loss of $\mathrm{Fe}(\mathrm{II})$ and $\mathrm{HF}$. 


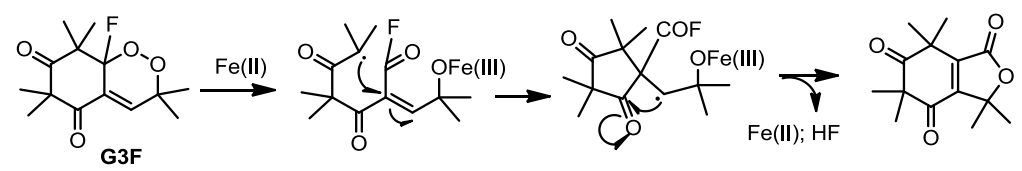

Scheme 7: Proposal of mechanism of Fe(II) induced reduction of G3F. endoperoxide.

In comparing the reduction of the three endoperoxides, we suggest a preponderant role of the tertiary C-centred radicals. The 5 exo-trig cyclisation will be more or less rapid depending on the substituent of the double bond (COOMe, $\mathrm{COOH}$ or $\mathrm{COF}$ ). In the case of the endoperoxide G3Me (3), the C-centered radical could last long enough to combine with haem (or to act on proteins), a reaction which is impeded when the intramolecular 5-exo-trig cyclisation occurs rapidly. This could explain why G3F (4) does not possess significant antiplasmodial activity and G3Me (3) is far more potent than G3 (2).

A relationship between antiplasmodial activity and a good balance between reactivity and stability of the C-centered radical is thus suggested. This $\mathrm{C}$-centered radical could then alkylate haem or parasitic vital proteins. On this basis we could explain why alkylation of the peroxyhemiketal function is crucial for antimalarial activity and how to design new compounds.

\section{Structural variations of the G-factors.}

Our synthetic strategy allows easy modifications of the endoperoxides by variation of the aldehydes $\left(\mathrm{R}^{1} \mathrm{R}^{2} \mathrm{CHCHO}\right)$ involved in the Mannich-type reaction. The use of various aldehydes permits the introduction of :

i) a lateral chain comprising a hydroxyl group for further functionalization

ii) $\quad \alpha$-spiro-alkyl moieties.

\subsection{Modifications on the lateral chain}

The use of aldehydes $\left(\mathrm{R}^{1} \mathrm{R}^{2} \mathrm{CHCHO}\right)$ with $\mathrm{R}^{1}$ or $\mathrm{R}^{2}$ bearing a hydroxyl group $\left(\mathrm{R}^{1}\right.$ or $\mathrm{R}^{2}$ equals to $\mathrm{CH}_{2} \mathrm{OH}$ or $\mathrm{CH}_{2} \mathrm{CH}_{2} \mathrm{OH}$, and $\mathrm{CH}_{3}$ ) allows the obtention of endoperoxides with a functionalized lateral chain which are presented in Table 2 together with their antiplasmodial activities. In all cases, this hydroxyl group was protected as a tert-butyldiphenyl silyl (TBDPS) [51, 61] or a paramethoxybenzyl (PMB) group.[62]

Methylation of the peroxyhemiketal moiety, cleavage of the protective group, and terminal hydroxyl transformation afforded mono and difluoro-endoperoxides $\mathbf{2 5}, \mathbf{2 6}$ with interesting antiplasmodial activities (lower than $1 \mu \mathrm{M}$ ). From this study, we can notice that methylation of the hydroxyl of the peroxo-hemiketal led to compounds with significant more powerful antiplasmodial activities in most cases excepted when TBDPS was introduced $(\mathbf{1 9}, \mathbf{2 1}$ versus $\mathbf{2 0}, \mathbf{2 2}$ and $\mathbf{2 7}, \mathbf{2 9}$ versus $\mathbf{2 8}, \mathbf{3 0})$. Lipophilicity was also of great importance as the deprotection of the hydroxyl group on the lateral chain led to less active compounds. Endoperoxides $\mathbf{2 8}$ and $\mathbf{3 2}$ are 115- and 52- times more potent than 35. This is even more striking with the endoperoxide 19 (0.62 $\mu \mathrm{M})$ which can be compared to the bis hydroxylated endoperoxide $\mathbf{2 3}$ which does not present antimalarial activity anymore $(>100 \mu \mathrm{M})$. Hydroxylated compounds 19, 21 and 27, 29 are the most potent of this series with $\mathrm{R}=\mathrm{OH}$. The lipophilicity afforded by the presence of the TBDPS group could explain the gain in activity. No increase in activity was observed on their methylated analogues 20, 22 and 28, 30. This observation let us think that the mechanism of the Fe(II)-induced reduction may be different than the one observed in the case of the $\mathbf{G 3}$ and G3Me. 
Table 2 In vitro antimalarial activity on Nigerian P. falciparum strains.

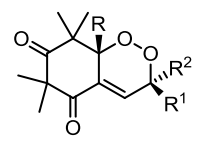

\begin{tabular}{|c|c|c|c|c|c|c|c|c|c|}
\hline compound & $\mathbf{R}$ & $\mathbf{R}^{1}$ & $\mathbf{R}^{2}$ & $\mathrm{IC}_{50}(\mu \mathrm{M})^{a}$ & compound & $\mathbf{R}$ & $\mathbf{R}^{1}$ & $\mathbf{R}^{2}$ & $\mathrm{IC}_{50}(\mu \mathrm{M})^{a}$ \\
\hline 2 & $\mathrm{OH}$ & $\mathrm{CH}_{3}$ & $\mathrm{CH}_{3}$ & 36 & 3 & $\mathrm{OCH}_{3}$ & $\mathrm{CH}_{3}$ & $\mathrm{CH}_{3}$ & 0.28 \\
\hline 15 & $\mathrm{OH}$ & $\mathrm{CH}_{3}$ & $\mathrm{Ph}$ & 25 & 16 & $\mathrm{OCH}_{3}$ & $\mathrm{CH}_{3}$ & $\mathrm{Ph}$ & 2.00 \\
\hline 17 & $\mathrm{OH}$ & $\mathrm{Ph}$ & $\mathrm{CH}_{3}$ & 27 & 18 & $\mathrm{OCH}_{3}$ & $\mathrm{Ph}$ & $\mathrm{CH}_{3}$ & 0.70 \\
\hline 19 & $\mathrm{OH}$ & $\mathrm{CH}_{3}$ & $\mathrm{CH}_{2} \mathrm{OTBDPS}$ & 0.62 & 20 & $\mathrm{OCH}_{3}$ & $\mathrm{CH}_{3}$ & $\mathrm{CH}_{2} \mathrm{OTBDPS}$ & 1.45 \\
\hline 21 & $\mathrm{OH}$ & $\mathrm{CH}_{2} \mathrm{OTBDPS}$ & $\mathrm{CH}_{3}$ & 0.45 & 22 & $\mathrm{OCH}_{3}$ & $\mathrm{CH}_{2} \mathrm{OTBDPS}$ & $\mathrm{CH}_{3}$ & 1.00 \\
\hline 23 & $\mathrm{OH}$ & $\mathrm{CH}_{3}$ & $\mathrm{CH}_{2} \mathrm{OH}$ & $>100$ & 24 & $\mathrm{OCH}_{3}$ & $\mathrm{CH}_{3}$ & $\mathrm{CH}_{2} \mathrm{OH}$ & 1.4 \\
\hline & & & & & 25 & $\mathrm{OCH}_{3}$ & $\mathrm{CH}_{3}$ & $\mathrm{CH}_{2} \mathrm{~F}$ & 0.69 \\
\hline & & & & & 26 & $\mathrm{OCH}_{3}$ & $\mathrm{CH}_{3}$ & $\mathrm{CHF}_{2}$ & 0.74 \\
\hline 27 & $\mathrm{OH}$ & $\mathrm{CH}_{3}$ & $\left(\mathrm{CH}_{2}\right)_{2} \mathrm{OTBDPS}$ & 0.74 & 28 & $\mathrm{OCH}_{3}$ & $\mathrm{CH}_{3}$ & $\left(\mathrm{CH}_{2}\right)_{2} \mathrm{OTBDPS}$ & 1.4 \\
\hline 29 & $\mathrm{OH}$ & $\left(\mathrm{CH}_{2}\right)_{2} \mathrm{OTBDPS}$ & $\mathrm{CH}_{3}$ & 0.73 & 30 & $\mathrm{OCH}_{3}$ & $\left(\mathrm{CH}_{2}\right)_{2} \mathrm{OTBDPS}$ & $\mathrm{CH}_{3}$ & 1.6 \\
\hline 31 & $\mathrm{OH}$ & $\mathrm{CH}_{3}$ & $\left(\mathrm{CH}_{2}\right)_{2} \mathrm{OPMB}$ & 10 & 32 & $\mathrm{OCH}_{3}$ & $\mathrm{CH}_{3}$ & $\left(\mathrm{CH}_{2}\right)_{2} \mathrm{OPMB}$ & 0.67 \\
\hline 33 & $\mathrm{OH}$ & $\left(\mathrm{CH}_{2}\right)_{2} \mathrm{OPMB}$ & $\mathrm{CH}_{3}$ & 9.9 & 34 & $\mathrm{OCH}_{3}$ & $\left(\mathrm{CH}_{2}\right)_{2} \mathrm{OPMB}$ & $\mathrm{CH}_{3}$ & 0.47 \\
\hline & & & & & 35 & $\mathrm{OCH}_{3}$ & $\mathrm{CH}_{3}$ & $\left(\mathrm{CH}_{2}\right)_{2} \mathrm{OH}$ & 73 \\
\hline
\end{tabular}

${ }^{a} \mathrm{IC}_{50}$ values are duplicated and were considered acceptable when values did not vary by more than a factor of 2.5 to 3 .

Introduction of mono or diamine frames, known to improve antiplasmodial activities by accumulation in the digestive vacuole of the parasite [63] and thereby increasing its acidic pH, was also accomplished (Scheme 8). Substitution of the chloromethyl sulfonyl group by substituted piperazines or mopholine allowed obtention of amino-endoperoxides 36a-36d in moderate to good yields (58-70\%). However, these endoperoxides (36a-d) have significant lower antiplasmodial activities with values ranging from 7.7 to $54 \mu \mathrm{M}$.[62] Presumably, these compounds did not reach the digestive vacuole of the parasite as they were too polar.

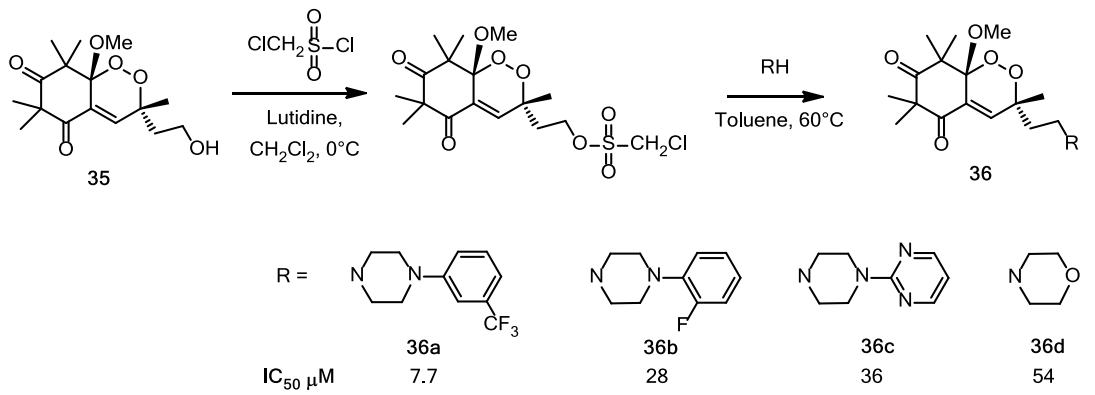

Scheme 8: Synthesis and in vitro antiplasmodial activities on Nigerian P. falciparum strains of amino-endoperoxides 36a-36d.

\section{2 $\alpha$-Spiro-endoperoxides synthesis}

The preparation of $\alpha$-spiro-endoperoxides was carried out in order to explore the possibility that the $\mathrm{Fe}(\mathrm{II})$-induced reduction leads to homolytic cleavage of the peroxo linkage following the competitive route $b$ ) in Scheme 9 . The $\mathrm{O}^{2}$-centered radical may then be formed and rearranged to the primary $\mathrm{C}$-centered radical, either via $\beta$-scission or via a secondary $\mathrm{C}$-centered radical followed by a 1,5-H shift. Primary and secondary C-centered radical are indeed produced after $\mathrm{Fe}(\mathrm{II})$ activation of artemisinin or artemisinin-like analogues with antiplasmodial activities. 


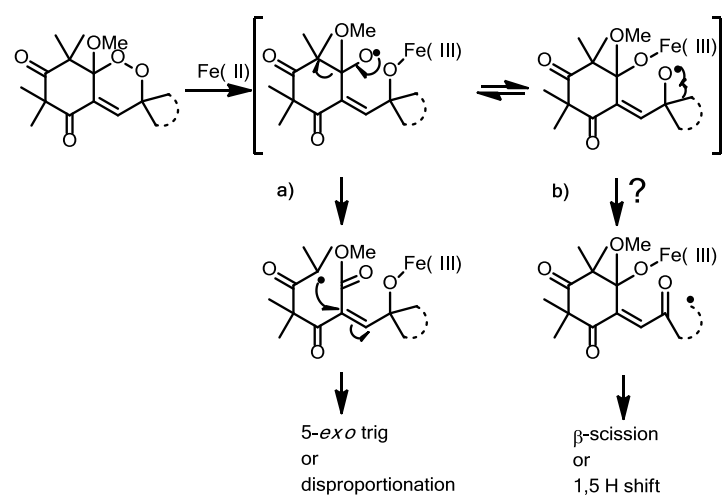

Scheme 9: Hypothesis of mechanism of Fe(II)-induced reduction of $\alpha$-spiro-endoperoxides.

In regard to that, the synthesis of an $\alpha$-cyclopropyl endoperoxide derivative which should provide a primary $\mathrm{C}$-centered radical after $\mathrm{Fe}(\mathrm{II})$ induced reduction was first considered. However, the endoperoxide could not be obtained since the precursor exists only in the enone form and could not be enolized, whatever photo-activation, acidic or basic treatment. Consequently, neither autoxidation nor photo-oxygenation (via singlet oxygen) could lead to the desired endoperoxide.

Variation of the ring size and use of more elaborated aldehydes, such as norbornene-carboxaldehyde (40, 45), or protected glyceraldehyde $(\mathbf{4 1}, \mathbf{4 6})$, were then investigated. The latter might be precursor to epoxide.

The endoperoxides obtained along with their methylated analogs are presented in Figure 3.
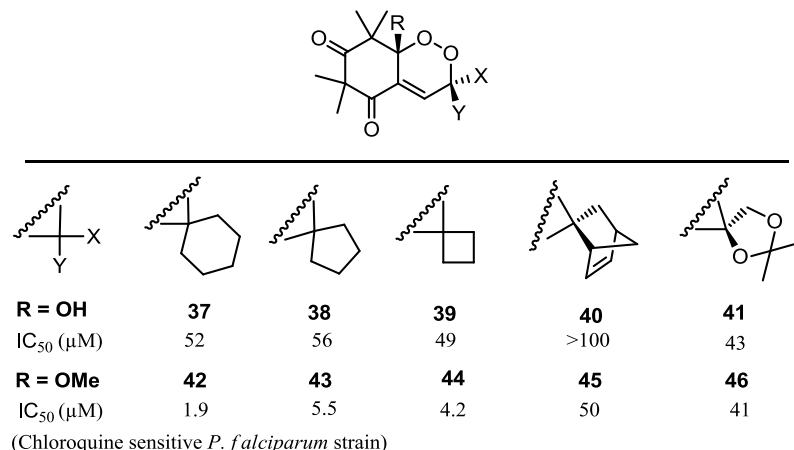

Figure 3: Antiplasmodial activities on Nigerian P. falciparum strains of $\alpha$-spiro endoperoxides.

They were prepared following the previously described methodology, and were evaluated for their antimalarial activities against a chloroquine sensitive Nigerian $P$. falciparum strains.[64] Methylation of the peroxyhemiketal of 37, 38, 39 very substantially increases their antimalarial activity from ten to thirty fold. In order to understand their mode of action, $\mathrm{Fe}$ (II) induced reduction was performed on cyclohexyl and cyclopentyl endoperoxides $\mathbf{3 7}$ and $\mathbf{3 8}$. The main products of the reaction were cyclopentyl (or cyclohexyl) ketone and the acid previously obtained during Fe(II) reduction of $\mathbf{G 3}$ (Scheme 5). As in the case of $\mathbf{G 3}$ reduction, only route a) is involved and the same Fe(II) induced degradation mechanism can be invoked. Norbornene (40) and acetonide (41) endoperoxides along with their methylated analogues $(\mathbf{4 5}, \mathbf{4 6})$ exhibited very low antimalarial activities with values of the same range for both hydroxylated and methylated compounds which is a clue for probably another type of $\mathrm{Fe}(\mathrm{II})$ degradation mechanism.

In conclusion, considering all endoperoxidic analogues of the G-factor family studied, G3Me (3) remains the lead compound with its potent in vitro antimalarial activity in the submicromolar range.

\subsection{Hybrid molecules}


A recent rational approach involving "covalent bitherapy" is based on the use of hybrid molecules with a dual mode of action.[7] The two active entities are covalently linked. These drugs allow bypassing the development of resistance, enhancing patient compliance and reducing drug-drug interactions. The synthesis of hybrid molecules containing an endoperoxide moiety linked to a second pharmacophore, e.g. a streptocyanine, a fluoroquinolone or a 4-amino-7-chloroquinoline, mimicking chloroquine was thus undertaken.

The reaction sequence to the amino-endoperoxide 47 capable of tighting a second pharmacophore is described in Scheme 10 . The piperidine moiety in spiro position of the cyclic peroxide was chosen in order to avoid the introduction of a second asymmetric center and obtention of diastereoisomeric mixture. Following the methodology previously described, methylation of the peroxyhemiketalic hydroxyl group, and subsequent tert-butyl-oxy-carbonyl (BOC) cleavage, amino-endoperoxide 47 was obtained. As expected, as $\mathbf{4 7}$ is more polar than G3Me, its antimalarial activity against Nigerian $P$. falciparum strain $(5.7 \mu \mathrm{M})$ was less potent than the G3Me $(0.28 \mu \mathrm{M})$.

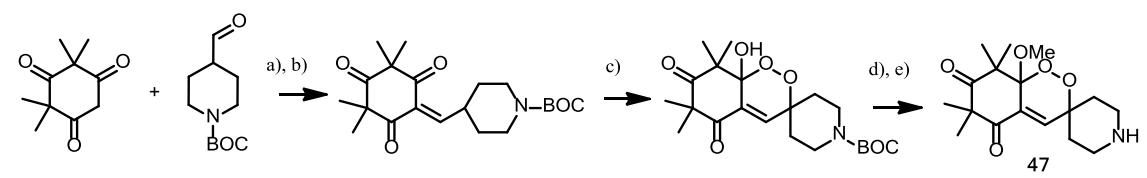

Scheme 10 : Synthesis of the amino-endoperoxide 47. a) piperidine, dichloromethane, RT, 95\%. b) $\mathrm{NH}_{4} \mathrm{Cl} / \mathrm{HCl} 1 \mathrm{~N}, 95 \%$. c) $\mathrm{O}_{2}$, EtOAc, $68 \%$. d) $\mathrm{BuLi} / \mathrm{MeOTf}$, THF, $-78^{\circ} \mathrm{C}, 62 \%$. e) TFA, $\mathrm{CH}_{2} \mathrm{Cl}_{2}, 95 \%$

\subsubsection{Streptocyanine-endoperoxide}

We previously described the synthesis of streptocyanine dyes as potential new antimalarial drugs. [65] SAR studies have shown the influence of the polymethine chain length $(5 \mathrm{C}-, 7 \mathrm{C}$ - or 9C-) and also the importance of the structural modifications at the nitrogen end groups. The most active compounds displayed sub-micromolar in vitro activities against $P$. falciparum and the best selectivity between activity and cytotoxicity toward mammalian cells was obtained for 5C-streptocyanines with morpholino end groups. Streptocyanines are obtained by reaction of carboxonium salts with amines. This methodology was used to design peroxo-streptocyanines containing both the endoperoxide moiety related to the G-factor and the streptocyanine. The target dual molecules synthesis was carried out either via the hemicarboxonium, or the more reactive but less stable carboxonium (Scheme 11). Symmetrical (48) and unsymmetrical compounds $(\mathbf{4 9}, \mathbf{5 0}, \mathbf{5 1})$ were obtained using this strategy.[66] Their antiplasmodial activities, against chloroquine sensitive (Nigerian) and resistant (FcB1-Columbia and FcM29-Cameroon) strains of P. falciparum are presented in Table 3 . All hybrid unsymmetrical molecules 49, $\mathbf{5 0}$ and $\mathbf{5 1}$ exhibited potent in vitro antiplasmodial activities $(0.039$ to $0.436 \mu \mathrm{M})$ similar or better than those of their corresponding streptocyanines $\mathbf{5 2}, \mathbf{5 3}, \mathbf{5 4}(0.085$ to $5.47 \mu \mathrm{M})$.[66]

Antiplasmodial activity is not improved by the introduction of two endoperoxide moieties as the hybrid symmetrical compound 48 did not display more potent $\mathrm{IC}_{50}$ values than its corresponding hybrid unsymmetrical compound $\mathbf{4 9}$ or streptocyanine $\mathbf{5 2}$.

Hybrid peroxo-streptocyanines are thus ten- to one hundred-fold more active than the cyclic peroxide 47 (IC $50.7 \mu \mathrm{M}$ ) which is likely too hydrophilic due to the NH group. Interestingly, hybrid

unsymmetrical compound $\mathbf{5 1}$ showed increased activities with regard to the corresponding symmetrical streptocyanine $\mathbf{5 3}$, with an $\mathrm{IC}_{50}$ very low: 0.057 and $0.039 \mu \mathrm{M}$ against respectively FcB1 and FcM29 P. falciparum strains and nearly 10-fold better than our lead actual lead compounds G3Me. 


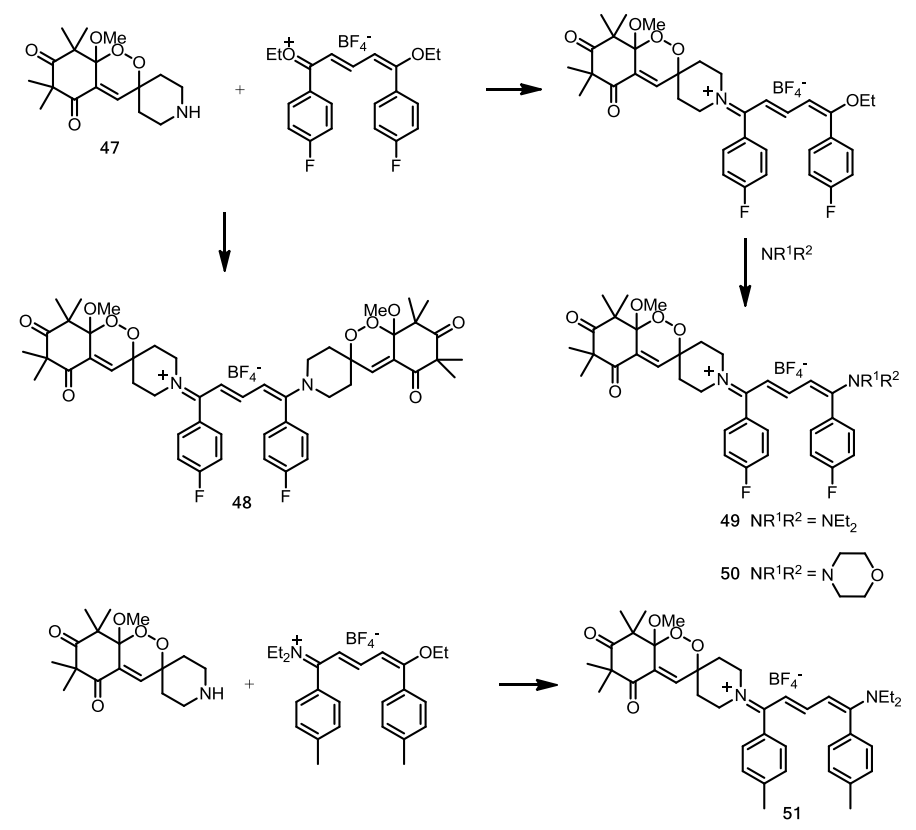

Scheme 11: Synthesis of symmetrical and unsymmetrical hybrid streptocyanines.

Table 3. In vitro activity of the synthesized compounds against chloroquine susceptible (Nigerian) and chloroquine resistant (FcB1, FcM29) strains of Plasmodium falciparum.

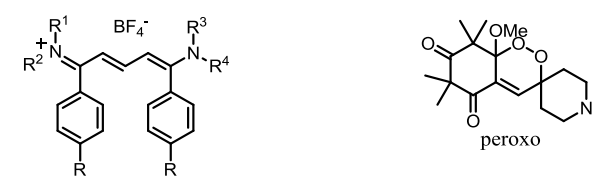

\begin{tabular}{|c|c|c|c|c|c|c|}
\hline \multirow[b]{2}{*}{ compound } & \multirow[b]{2}{*}{$\mathrm{NR}^{1} \mathrm{R}^{2}$} & \multirow[b]{2}{*}{$N^{3} R^{4}$} & \multirow[b]{2}{*}{$\mathrm{R}$} & \multicolumn{3}{|c|}{$\mathrm{IC}_{50} P$. falciparum $(\mu \mathrm{M})$} \\
\hline & & & & Nigerian $^{a}$ & $\mathrm{FcB}^{b}{ }^{b}$ & $\mathrm{FcM} 29^{b}$ \\
\hline 52 & $\mathrm{NEt}_{2}$ & $\mathrm{NEt}_{2}$ & $\mathrm{~F}$ & 0.15 & 0.248 & 0.465 \\
\hline 49 & $\mathrm{NEt}_{2}$ & peroxo & $\mathrm{F}$ & 0.10 & 0.436 & 0.422 \\
\hline 48 & peroxo & peroxo & $\mathrm{F}$ & 0.645 & 0.294 & 0.366 \\
\hline 53 & $\mathrm{NEt}_{2}$ & $\mathrm{NEt}_{2}$ & $\mathrm{Me}$ & 0.13 & 0.420 & 0.085 \\
\hline 51 & $\mathrm{NEt}_{2}$ & peroxo & $\mathrm{Me}$ & - & 0.057 & 0.039 \\
\hline 54 & & & $\mathrm{~F}$ & 0.73 & 5.47 & 3.22 \\
\hline 50 & $N$ & peroxo & $\mathrm{F}$ & 0.305 & 0.427 & 0.374 \\
\hline Artemisinin & - & & - & 0.008 & - & 0.004 \\
\hline Chloroquine & - & & - & 0.03 & 0.132 & 0.26 \\
\hline
\end{tabular}

${ }^{a}$ Values reflect the mean of two experiments carried out in duplicate. ${ }^{b}$ Values reflect the mean of three independent experiments, as SD was constantly lower than $15 \%$ they were not indicated in the table.

\subsubsection{Ciprofloxacin-endoperoxide}

The ciprofloxacin is a second generation of fluoroquinolone antibiotic. Fluoroquinolones affect bacterial DNA by targeting two essential enzymes, DNA gyrase and topoisomerase IV that belong to the type II topoisomerase family. Ciprofloxacin acts by forming a quaternary drug-topoisomerase-DNA complex involving $\mathrm{Mg}^{2+}$ that causes DNA to rewind after being copied, stopping thus DNA and protein synthesis resulting in cell death. This antibiotic was also reported to be active against $P$. falciparum [67] 
with an $\mathrm{IC}_{50}$ of $50 \mu \mathrm{M}$ against chloroquine sensitive 3D7 strains.[68] Gyrase has moreover been localized in the apicoplast of the malarial parasite Plasmodium falciparum.[69]

To bring together the mode of action of endoperoxide, potentially capable to alkylate haem and the fluoroquinolone capable to inhibit DNA replication, the two pharmacophores were covalently linked to furnish a compound acting or in the digestive vacuole or in the apicoplast of the Plasmodium. Ciprofloxacine was first added to succinic anhydride leading to the corresponding acid in $76 \%$ yield (Scheme 12). A peptidic coupling using EDCI/HOBt (N-ethyl-N'-dimethylaminopropylcarbodiimide, /1hydroxybenzotriazole) was then used involving both entities providing after purification by column chromatography the hybrid molecule $\mathbf{5 5}$ in $44 \%$ yield. [70]
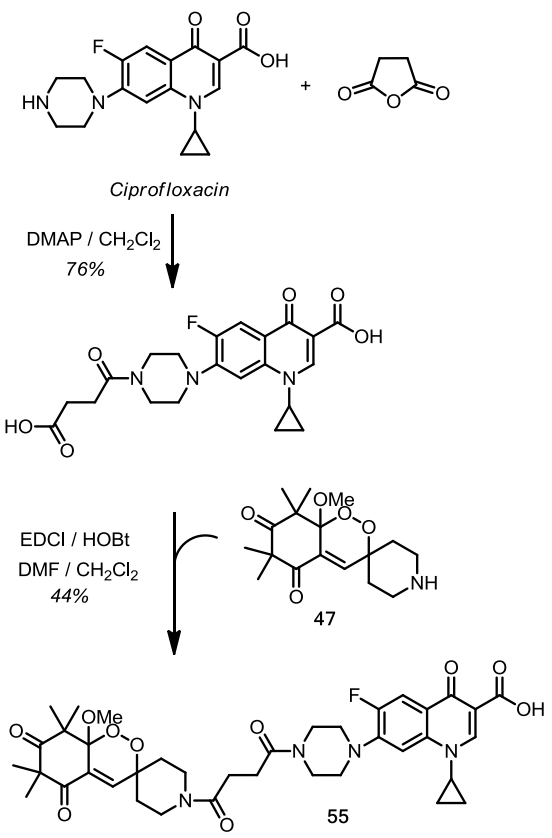

Scheme 12: Synthesis of ciprofloxacine-endoperoxide hybrid molecule 55.

The activity of the hybrid molecule $\mathbf{5 5}$ was of $1.2 \mu \mathrm{M}$ against the chloroquine susceptible Nigerian $P$. falciparum strain. Although this compound is slightly more potent than the amino-endoperoxide $47\left(\mathrm{IC}_{50} 5.7 \mu \mathrm{M}\right)$, it is 50 -fold more active than ciprofloxacin against chloroquine susceptible strain. It can also be compared with the new promising prodrugs of ciprofloxacin developed by Biot et al. which present activities ten to one hundred better than ciprofloxacin [68]. Their hydrophobic properties lead indeed, to a better penetration capacity through the multiple membranes of the apicoplast before targeting DNA gyrase.[71]

Ciprofloxacin derivatives or hybrid molecules based on fluoroquinolone pharmacophore could represent a new promising class of antimalarial drugs, and in a larger context, quinolone family could represent a new antimalarial series as Riscoe's team identified potent and selective quinolone-3-diarylether with good activity against $P$. falciparum both in vitro and in vivo. [72]

\subsubsection{4-Aminoquinoline-endoperoxide}

Several strategies were investigated to design hybrids of 4-amino-7-chloroquinoline-endoperoxide, with various cyclic and acyclic links. The first one was a peptidic coupling between the amino-endoperoxide 47 and the 4-amino-7-chloroquinoline intermediate acids $(\mathbf{5 6}, \mathbf{5 7})$. The synthesis of both hybrid compounds is described in Scheme 13. The intermediate acids $(\mathbf{5 6}, \mathbf{5 7})$ were obtained quantitatively by reaction of the succinic anhydride with the two amino derivatives of the 7-chloroquinoline.[66] Then, the coupling was carried out between the amino-endoperoxide 47 and the intermediate acids $(\mathbf{5 6}, \mathbf{5 7})$ using the reagent HBTU (O-Benzotriazole-N,N,N',N'-tetramethyl-uronium-hexafluoro-phosphate) and di-isopropylethylamine. 
<smiles>Clc1ccc2c(N3CCNCC3)ccnc2c1</smiles><smiles>O=C(O)CCC(=O)N1CCN(c2ccnc3cc(Cl)ccc23)CC1</smiles>

56

b)

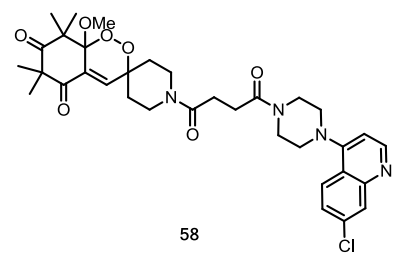<smiles></smiles>

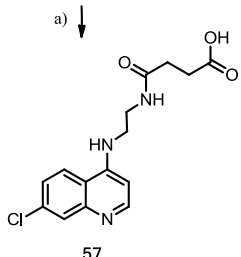

b)

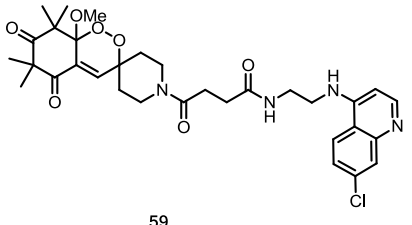

Scheme 13: Synthesis of hybrid 4-amino-7-chloroquinoline-endoperoxides $\mathbf{5 8}, \mathbf{5 9}$ related to G-factors: a) succinic anhydride, $\mathrm{DMAP} \mathrm{CH}_{2} \mathrm{Cl}_{2}, 72 \%(\mathbf{5 6})$ and $86 \%$ (57) b) 47, $\mathrm{HBTU},(i-\operatorname{Pr})_{2} \mathrm{EtN}, \mathrm{CH}_{2} \mathrm{Cl}_{2}, 0$ to $25^{\circ} \mathrm{C}, 77 \%(\mathbf{5 8})$ and $70 \%(\mathbf{5 9})$.

The second strategy involved linking the 7-chloroquinoline directly or via an amino ethylene coupling arm to the piperidineendoperoxide moiety. As the direct coupling was not successful, the 7-chloroquinoline was attached before the autoxidation step, with or without the linker as described in respectively Schemes 14 and 15.

Starting from the 4,7-dichloroquinoline, aldehyde $\mathbf{6 0}$ was obtained after substitution of one chloride by the 4-piperidinylmethanol followed by oxidation with 2-iodoxybenzoic acid (IBX) in acetone. The so-obtained aldehyde could react with syncarpic acid in previous modified Knoevenagel conditions giving the precursor $\mathbf{6 1}$ which after slow oxygen uptake provide the expected endoperoxide $\mathbf{6 2}$ in $54 \%$ on the two last steps. It was then methylated using BuLi/MeOTf, at low temperature giving $\mathbf{6 3}$ in $50 \%$ yield.
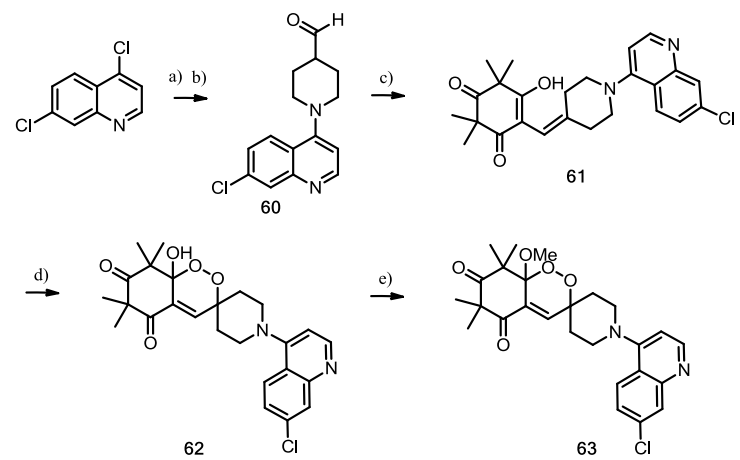

Scheme 14: Synthesis of hybrid 4-amino 7-chloroquinoline-endoperoxides 62, 63 related to G-factors: a) 4-piperidinyl-methanol, $\mathrm{K}_{2} \mathrm{CO}_{3}, \mathrm{DMF}, 170^{\circ} \mathrm{C}$, $91 \%$ b) IBX, acetone, $60^{\circ} \mathrm{C}, 99 \%$ c) syncarpic acid, piperidine then $\mathrm{NH}_{4} \mathrm{Cl} / \mathrm{HCl} 1 \mathrm{~N} \mathrm{~d}$ ) $\mathrm{O}_{2}, \mathrm{EtOAc}, 54 \%$ e) $\mathrm{BuLi}, \mathrm{MeOTf},-78^{\circ} \mathrm{C}, 50 \%$.

The same strategy was used to prepare endoperoxides 67 and 68.4 -aminoquinoline 64 was firstly prepared by reaction of the 4,7-dichloroquinoline with ethanolamine at reflux, followed by tosylation of the hydroxyl in a $90 \%$ yield for the two steps. After substitution of the tosyl group by 4-piperidinyl-methanol, followed by oxidation with IBX in DMSO, the aldehyde 65 was obtained in $45 \%$ yield. As previously described, dienol 66 could be obtained within Knoevenagel modified conditions between syncarpic acid and aldehyde $\mathbf{6 5}$. After a slow oxygen uptake (15 days) in dichloromethane, the endoperoxide $\mathbf{6 7}$ was obtained in $61 \%$ yield as the salt of the trifloroacetic acid. Finally, methylation with BuLi/MeOTf, at low temperature furnished the target endoperoxide $\mathbf{6 8}$ with $27 \%$ yield. 

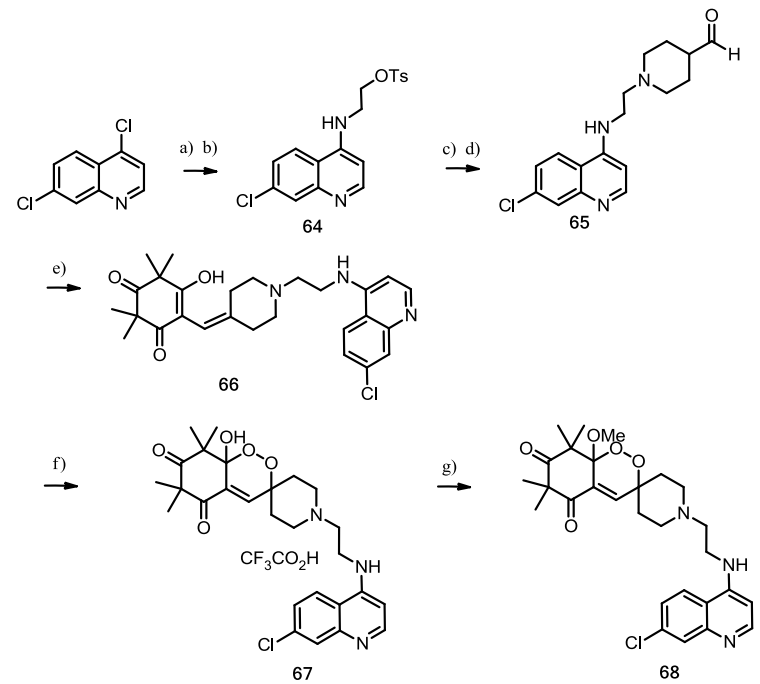

Scheme 15 : Synthesis of hybrid 4-ethylamino-7-chloroquinoline-endoperoxides 67, 68 related to G-factors: a) ethanolamine, reflux $95 \%$ b) TsCl, pyridine, $95 \%$ c) 4-piperidinyl-methanol, $\mathrm{K}_{2} \mathrm{CO}_{3}, \mathrm{DMF}, 160^{\circ} \mathrm{C}, 85 \%$, d) IBX, TFA, DMSO , 45\%, e) syncarpic acid, piperidine then $\mathrm{NH} \mathrm{Cl}_{4} \mathrm{Cl} / \mathrm{HCl} 1 \mathrm{~N}$, f) $\mathrm{O}_{2}, \mathrm{CH}_{2} \mathrm{Cl}_{2}$, TFA (1eq), $61 \%$, g) BuLi, $\mathrm{MeOTf},-78^{\circ} \mathrm{C}, 27 \%$.

These hybrid endoperoxides were evaluated in vitro, on both chloroquine susceptible and resistant strains (3D7 and W2 respectively). Values of the antiplasmodial activities are presented in Table 4. From these values, it seems that a link is necessary between the 4-amino-7-chloroquinoline part and the endoperoxide moiety as hybrid compounds $\mathbf{6 2}$ and $\mathbf{6 3}$ are the less potent of the series. Introduction of the ethylene link within compounds 67, 68 affords an increase in activity with values around $100 \mathrm{nM}$, these compounds being slightly more potent than G3Me. But the best improvements were obtained using a peptidic coupling between the amino-endoperoxide and the intermediate acids obtained by reaction of the succinic anhydride with the two cyclic and acyclic amino derivatives of the 7-chloroquinoline furnishing the hybrids $\mathbf{5 8}$ and $\mathbf{5 9}$. The compound $\mathbf{5 9}$ is the most potent with an $\mathrm{IC}_{50}$ of $31 \mathrm{nM}$ on $3 \mathrm{D} 7$ and of $13 \mathrm{nM}$ on W2. It is noteworthy that $\mathrm{IC}_{50}$ of endoperoxides are generally lower on chloroquine resistant strain than on sensitive strain as it is the case for this compound. It seems that for this compound both the peroxide and the 4-amino-7-chloroquinoline moieties afford activity. This compound is indeed more potent than chloroquine alone on W2 and in the same range on 3D7. Moreover, it is 10-fold better than G3Me on both strains.

Table 4: In vitro activity of the synthesized compounds against chloroquine susceptible (3D7) and chloroquine resistant (W2) strains of $P$. falciparum.

\begin{tabular}{cccccccccc}
\hline & \multicolumn{9}{c}{ IC $_{\mathbf{5 0}}(\mathbf{n M})$} \\
\cline { 2 - 9 } strains & chloroquine & artemisinin & $\mathbf{G 3 M e}$ & $\mathbf{5 8}$ & $\mathbf{5 9}$ & $\mathbf{6 2}$ & $\mathbf{6 3}$ & $\mathbf{6 7}$ \\
\hline 3D7 & 24 & 19 & 405 & 130 & 31 & 4400 & 230 & 90 \\
\hline W2 & 420 & 4 & 137 & 86 & 13 & 870 & 97 & 106 \\
\hline
\end{tabular}

\section{Conclusion}

Synthesis of bicyclic peroxides related to the G-factor family was developed based on an autoxidation step to introduce the O-O bond. This methodology allows preparation of a large family of endoperoxides. An extensive electrochemical study of the dissociative electron transfer allows us to understand the mechanism implied during the electron transfer and then a chemical study, the characterization of the radical species obtained after iron(II) induced reduction. The endoperoxide moiety has been linked to other active compounds furnishing hybrid molecules. An increase in antiplasmodial activity was observed for some of them, especially for two kinds of hybrids: endoperoxide-streptocyanine $\mathbf{5 3}$ and endoperoxide-7-chloro-4-aminoquinoline $\mathbf{5 9}$ for which activities are in the low nanomolar range (10 to $50 \mathrm{nM})$. 


\section{ACKNOWLEDGMENT}

The authors thank the "Ministère de l'Education Nationale" for the grant of J. Ruiz.

\section{REFERENCES}

[1] http://www.who.int/malaria/publications/world_malaria_report_2012/en

[2] Cox-Singh, J.; Davis, T.; Lee K.; Shamsul S.; Matusop, A.; Ratnam, S.; Rahman, H.; Conway, D.; Singh, B. Plasmodium knowlesi malaria in humans is widely distributed and potentially life threatening. Clinical infectious diseases, 2008, 46(2), 165-171.

[3] Wells, T.N.; Alonso, P.L.; Gutteridge, W.E. New medicines to improve control and contribute to the eradication of malaria. Nat Rev Drug Discov., 2009, 8(11), 879-91.

[4] Anthony, M.P.; Burrows, J.N.; Duparc, S.; Moehrle J.J.; Wells T.N. The global pipeline of new medicines for the control and elimination of malaria. Malaria Journal, 2012, 11, 316.

[5] Jefford, C.W.; McCoran, E.C.; Boukouvalas, J.; Richardson, G.; Robinson, B. L.; Peters, W. Synthesis of new 1,2,4-trioxanes and their antimalarial activity, Helv. Chim. Acta, 1988, 71, 1805-1812.

[6] Jefford, C.W. Synthetic peroxides as potent antimalarials. News and views, Current Topics in Medicinal Chemistry, 2012, 12, 373-399.

[7] Dechy-Cabaret, O.; Benoit-Vical, F.; Loup, C.; Robert, A.; Gornitzka, H.; Bonhoure, A.; Vial, H.; Magnaval, J.-F.; Séguéla, J.-P.; Meunier, B. Synthesis and antimalarial activity of trioxaquine derivatives, Chem. Eur. J., 2004, 10, 1625-1636.

[8] Singh, C.; Malik, H.; Puri, S.K. Orally active 1,2,4-trioxanes: Synthesis and antimalarial assessment of a new series of 9-functionalized 3-(1arylvinyl)-1,2,5-trioxaspiro[5.5]undecanes against multi-drug-resistant Plasmodium yoelii nigeriensis in mice. J. Med. Chem., 2006, 49, 2794-2803.

[9] O’Neill, P.M.; Rawe, S.L.; Borstnik, K.; Miller, A.; Ward, Q.A.; Bray, P.G.; Davies, J.; Oh, C. H.; Posner, G.H.. Enantiomeric 1,2,4trioxanes display equivalent in vitro antimalarial activity versus Plasmodium falciparum malaria parasites: implications for the molecular mechanism of action of the artemisinins. ChemBioChem, 2005, 6, 2048-2054.

[10] Vennerstrom, J.L.; Arbe-Barnes, S.; Brun, R.; Charman, S.A.; Chiu, F.C.K.; Chollet, J.; Dong, Y.; Dorn, A.; Hunziker, D.; Matile, H.; McIntosh, K.; Padmanilayam, M.; Santo Tomas, J.; Scheurer, C.; Scorneaux, B.; Tang, Y.; Urwyler, H.; Wittlin, S.; Charman, W.N. Identification of an antimalarial synthetic trioxolane drug development candidate. Nature, 2004, 430, 900-904.

[11] Charman, S.A.; Arbe-Barnes, S.; Bathurst, I.C.; Brun, R.; Campbell, M.; Charman, W.N. ; Chiu, F.C.K. ; Chollet, J.; Craft, J.C.; Creek, D.J.; Dong, Y.; Matile, H.; Maurer, M.; Morizzi, J.; Nguyen, T.; Papastogiannidis, P.; Scheurer, C.; Shackleford, D.M.;Sriraghavan, K.; Stingelin, L.; Tang, Y.; Urwyler, H.; Wang, X.; White, K.L. ; Wittlin, S.; Zhou, L.; Vennerstrom, J.L. Synthetic ozonide drug candidate OZ439 offers new hope for a single-dose cure of uncomplicated malaria. Proc. Natl. Acad. Sci. USA, 2011, 108, $4400-4405$.

[12] Terent'ev, A.O.; Borisov, D.A.; Vil',V.A.; Dembitsky V. M. Synthesis of five and six-membered cyclic organic peroxides: Key transformations into peroxide ring-retaining products. Belstein J. Org. Chem., 2014, 10, 34-114.

[13] Posner, G.H.; O’Dowd, H.; Ploypradith, P.; Cumming, J.N.; Xie, S.; Shapiro, T. Antimalarial cyclic peroxy ketals. J. Med. Chem., 1998, $41,2164-2167$.

[14] Hofheinz, W.; Burgin, H.; Gocke, E.; Jaquet, C.; Masciadri, R.; Schmid, G.; Stohler, H.; Urwyler, H. RO-42-1611 (arteflene), a new effective antimalarial - chemical-structure and biological-activity. Trop. Med. Parasitol., 1994, 45, 261-265.

[15] Bachi, M.D.; Korshin, E.E.; Hoos, R.; Szpilman, A.M.; Ploypradith, P.; Xie, S.; Shapiro, T.; Posner, G.H. A short synthesis and biological evaluation of potent and nontoxic antimalarial bridged bicyclic beta-sulfonyl-endoperoxides. J. Med. Chem., 2003, 46, $2516-2533$.

[16] O’Neill, P.M.; Stocks, P.A.; Pugh, M.D.; Araujo, N.C.; Korshin, E.E.; Bickley, J.F.; Ward, S.A.; Bray, P.G.; Pasini, E.; Davies, J.; Verissimo, E.; Bachi, M.D. Design and synthesis of endoperoxide antimalarial prodrug models. Angew. Chem. Int. Ed., 2004, 43, 41934197.

[17] Zmitek, K.; Zupan, M.; Iskra, J. alpha-Substituted organic peroxides: synthetic strategies for a biologically important class of gemdihydroperoxide and perketal derivatives. Org. Biomol. Chem., 2007, 5, 3895-3908.

[18] Subramanyam, V.; Brizuela, C.L.; Soloway, A.H. Synthesis and reactions of beta-hydroxyhydroperoxides, J. Chem. Soc., Chem. Commun., 1976, 508-509.

[19] Sanderson, J.R.; Paul, K.; Story, P.R.; Denson, D.D.; Alford, J.A. Macrocycles - synthesis and thermal-decomposition of some disubstituted dicyclohexylidene diperoxides. Synthesis, 1975, 159-161.

[20] Vennerstrom, J.L.; Fu, H.-N.; Ellis, W.Y.; Ager, A.L.; Wood, J.K.; Andersen, S.L.; Gerena, L.; Milhous, W.K. Dispiro-1,2,4,5-tetraoxanes - a new class of antimalarial peroxides J. Med. Chem., 1992, 35, 3023-3027.

[21] Wang, X.; Dong, Y.; Creek, D.; Chollet, J.; Charman, S.A.; Tomas, J.S.; Scheurer, C.; Snyder, C.; Vennerstrom, J.L. Spiro- and dispiro1,2-dioxolanes: contribution of iron(II)-mediated one-electron vs two-electron reduction to the activity of antimalarial peroxides. J. Med. Chem., 2007, 50, 5840-5847.

[22] Zhang, Q.; Jin, H.X.; Wu, Y. A facile access to bridged 1,2,4-trioxanes. Tetrahedron, 2006, 62, 11627-11634.

[23] Murakami, N.; Kawanishi, M.; Horii, T.; Kobayashi, M. Facile construction of 6-carbomethoxymethyl-3-methoxy-1,2-dioxane, a core structure of spongean anti-malarial peroxides. Tetrahedron Lett., 2001, 42, 7281-7285.

[24] Murakami, N.; Kawanishi, M.; Horii, T.; Kobayashi, M. New readily accessible peroxides with high anti-malarial potency. Bioorg. Med. Chem. Lett., 2002, 12, 69-72. 
[25] Tang, Y.; Dong, Y.; Wang, X.; Sriraghavan, K.; Wood, J. K.; Vennerstrom, J. L. Dispiro-1,2,4-trioxane analogues of a prototype dispiro1,2,4-trioxolane: Mechanistic comparators for artemisinin in the context of reaction pathways with iron(II) J. Org. Chem., 2005, 70, 51035110 .

[26] O’Neill, P.M.; Searle, N.L.; Raynes, K.J.; Maggs, J.L.; Ward, S.A.; Storr, R.C.; Park, B.K.; Posner, G.H. A carbonyl oxide route to antimalarial yingzhaosu A analogues: Synthesis and antimalarial activity. Tetrahedron Lett., 1998, 39, 6065-6068.

[27] Dai, P.; Dussault, P.H. Intramolecular reactions of hydroperoxides and oxetanes: Stereoselective synthesis of 1,2-dioxolanes and 1,2dioxanes. Org. Lett., 2005, 7, 4333-4335.

[28] Ushigoe, Y.; Kano, Y.; Nojima, M. Synthesis of 1,2,4-trioxanes and 1,2,4-trioxepanes by N-halogenosuccinimide-mediated cyclisations of unsaturated hydroperoxyacetals. J. Chem. Soc., Perkin Trans., 1 1997, 5-10.

[29] Dong, Y.; Vennerstrom, J.L. Dispiro-1,2,4,5-tetraoxanes via ozonolysis of cycloalkanone O-methyl oximes: A comparison with the peroxidation of cycloalkanones in acetonitrile-sulfuric acid media . J. Org. Chem., 1998, 63, 8582-8585

[30] Vennerstrom, J.L.; Arbe-Barnes, S.; Brun, R.; Charman, S.A.; Chiu, F.C.K.; Chollet, J.; Dong, Y.; Dorn, A.; Hunziker, D.; Matile, H.; McIntosh, K.; Padmanilayam, M.; Santo Tomas, J.; Scheurer, C.; Scorneaux, B.; Tang, Y.; Urwyler, H.; Wittlin, S.; Charman, W.N. Identification of an antimalarial synthetic trioxolane drug development candidate. Nature, 2004, 430, 900-904.

[31] Charman, S. A; Arbe-Barnes, S.; Bathurst, I. C.;Brun, R.; Campbell, M.; Charman, W. N. ; Chiu, F. C. K.; Chollet, J.; Craft, J. C.; Creek, D. J.; Dong, Y.; Matile, H.; Maurer, M.; Morizzi, J.; Nguyen, T.; Papastogiannidis, P.; Scheurer, C.; Shackleford, D. M.; Sriraghavan, K.; Stingelin, L.; Tang, Y.; Urwyler, H.; Wang, X.; White, K.; Wittlin, S.; Zhou, L.; Vennerstrom, J. L. Synthetic ozonide drug candidate OZ439 offers new hope for a single-dose cure of uncomplicated malaria, Proc Natl Acad Sci U.S.A., 2011, 108(11), 4400-4405.

[32] http://www.mmv.org/research-development/rd-portfolio

[33] Singh, C. Preparation of beta-hydroxyhydroperoxides by photooxygenation of allylic alcohols and their elaboration into 1,2,4-trioxanes. Tetrahedron Lett., 1990, 31, 6901-6902.

[34] Bloodworth, A.J.; Shah, A. A halogenocyclization route to 1,2,4-trioxanes. Tetrahedron Lett., 1993, 34, $6643-6646$.

[35] Bloodworth, A.J.; Shah, A. Synthesis of 1,2,4-trioxanes via intramolecular oxymercuriation. J. Chem. Soc., Chem. Commun., 1991, 947948.

[36] Jefford, C.W.; Kohmoto, S.; Jaggi, D.; Timari, G.; Rossier, J.-C.; Rudaz, M.; Barbuzzi, O.; Gérard, D.; Burger, U.; Kamalaprija, P.; Mareda, J.; Bernardinelli, G. Synthesis, structure, and antimalarial activity of some enantiomerically pure, cis-fused cyclopenteno-1,2,4trioxanes. Helv. Chim. Acta, 1995, 78, 647-662.

[37] Dechy-Cabaret, O.; Benoit-Vical, F.; Robert, A.; Meunier, B. Preparation and antimalarial activities of "trioxaquines", new modular molecules with a trioxane skeleton linked to a 4-aminoquinoline. ChemBioChem., 2000, 4, 281-283

[38] Jefford, C.W.; Velarde, J.A.; Bernardinelli, G.; Bray, D.H.; Warhurst, D.C.; Milhous, W.K. Synthesis, structure, and antimalarial activity of tricyclic 1,2,4-trioxanes related to artemisinin. Helv. Chim. Acta, 1993, 76, 2775-2788.

[39] Posner, G.H.; O'Dowd, H.; Caferro, T.; Cumming, J.N.; Ploypradith, P.; Xie, S.; Shapiro, T.A. Antimalarial sulfone trioxanes. Tetrahedron Lett., 1998, 39, 2273-2276.

[40] O'Neill, P.M.; Hindley, S.; Pugh, M.D.; Davies, J.; Bray, P.G.; Park, B.K.; Kapu, D. S.; Ward, S.A.; Stocks, P.A. Co(thd)(2): a superior catalyst for aerobic epoxidation and hydroperoxysilylation of unactivated alkenes: application to the synthesis of spiro-1,2,4-trioxanes. Tetrahedron Lett., 2003, 44, 8135-8138.

[41] Bachi, M.D.; Korshin, E.E.; Ploypradith, P.; Cumming, J.N.; Xie, S.; Shapiro, T.A.; Posner, G.H. Synthesis and in vitro antimalarial activity of sulfone endoperoxides. Bioorg. Med. Chem. Lett., 1998, 8, 903-908.

[42] O'Neill, P.M.; Mukhtar, A.; Ward, S.A.; Bickley, J.F.; Davies, J.; Bachi, M.D.; Stocks, P.A. Application of thiol-olefin co-oxygenation methodology to a new synthesis of the 1,2,4-trioxane pharmacophore. Org. Lett., 2004, 6, 3035-3038.

[43] Posner, G.H.; O’Dowd, H.; Ploypradith, P.; Cumming, J.N.; Xie, S.; Shapiro, T.A. Antimalarial cyclic peroxy ketals. J. Med. Chem., 1998, 41, 2164-2167.

[44] Snider, B.; Shi, Z. Total synthesis of (+/-)-Chondrillin, (+/-)-Plakorin, and related peroxy ketals - development of a general-route to 3,6dihydro-1,2-dioxin-3-ols. J. Am. Chem. Soc., 1992, 114, 1790-1800.

[45] Baumstark, A.; Vasquez, P. Synthesis of pentasubstituted 3-hydroxy-1,2-dioxolanes. J. Org. Chem., 1992, 57, 393-395.

[46] Slack, R.; Jacobine, A.M.; Posner, G.H. Antimalarial peroxides: advances in drug discovery and design. MedChemComm 2012, 3, $281-297$.

[47] Ghisalberti, E.L. Bioactive acylphloroglucinol derivatives from Eucalyptus species. Phytochemistry, 1996, 41, 7-22, and references cited herein.

[48] Bolte, M. L.; Crow, W. D.; Yoshida, S. Plant-growth regulators in Eucalyptus-grandis .4. Synthetic approaches to G-regulator analogs. Aust. J. Chem., 1982, 35, 1411-1419.

[49] Gavrilan, M.; André-Barrès, C.; Baltas, M.; Tzedakis, T.; Gorrichon, L. Bicyclic peroxydes in the G factors series: synthesis and electrochemical studies.Tetrahedron Lett., 2001, 42, 2465-2468.

[50] Triquigneaux, M.; Charles, L.; André-Barrès, C.; Tuccio, B. A combined spin trapping/EPR/mass spectrometry approach to study the formation of a cyclic peroxide by dienolic precursor autoxidation. Org. Biomol. Chem, 2010, 8, 1361-1367.

[51] Najjar, F.; Baltas, M.; Gorrichon, L.; Moreno, Y.; Tzedakis, T.; Vial, H.; André-Barrès, C. Synthesis and electrochemical studies of new antimalarial endoperoxides. Eur. J. Org. Chem., 2003, 17, 3335-3343.

[52] Najjar, F.; Gorrichon, L.; Baltas, M.; Vial, H.; Tzedakis, T.; André-Barrès, C. Crucial role of the peroxyketal function for antimalarial activity in the G-factor series. Bioorg. Med. Chem. Lett., 2004, 14, 1433-1436.

[53] Najjar, F.; Gorrichon, L.; Baltas, M.; André-Barrès, C.; Vial, H. Alkylation of natural endoperoxide G3-factor. Synthesis and antimalarial activity studies. Org. Biomol. Chem., 2005, 3, 1612-1614.

[54] Meshnick, S.R.; Thomas, A.; Ranz, A.; Xu, C.M.; Pan, H.Z. Artemisinin (qinghaosu): The role of intracellular hemin in its mechanism of antimalarial action. Mol. Biochem. Parasitol., 1991, 49, 181-189.

[55] Zhang, F.; Gosser, D.K., Jr.; Meshnick, S.R. Hemin-catalyzed decomposition of artemisinin (qinghaosu). Biochem. Pharmacol., 1992, 43, $1805-1809$.

[56] Meshnick, S.R.; Yang, Y.Z.; Lima, V.; Kuypers, F.; Kamchonwongpaisan, S.; Yuthavong, Y. Iron-dependent free radical generation from the antimalarial agent artemisinin (qinghaosu). Antimicrob. Agents Chemother., 1993, 37, 1108-1114. 
[57] Najjar, F.; André-Barrès, C.; Baltas, M.; Lacaze-Dufaure, C.; Magri, D.C.; Workentin, M. S.; Tzedakis, T. Electrochemical reduction of G3-factor endoperoxide and its methyl ether: Evidence for a competition between concerted and stepwise dissociative electron transfer. Chem. Eur. J., 2007, 13, 1174-1179.

[58] Lacaze-Dufaure, C; Najjar F.; André-Barrès, C. First computational evidence of a competitive stepwise and concerted mechanism for the reduction of antimalarial endoperoxides. J. Phys. Chem. B, 2010, 114, 9848-9853.

[59] André-Barrès, C.; Najjar, F.; Bottalla, A.-L.; Massou, S.; Zedde, C.; Baltas, M.; Gorrichon, L. Fe(II)-induced reduction of labelled endoperoxides. NMR degradation studies on G3 factor and its methyl ether. J. Org. Chem., 2005, 70, 6921-6924.

[60] Spiller, D.G.; Bray, P.G.; Hughes, R.H.; Ward, S.A.; White M.R.H. The pH of the Plasmodium falciparum digestive vacuole: holy grail or dead-end trail? Trends in parasitology, 2002, 18, 441-444.

[61] Givelet, C.; Bernat, V.; Danel, M.; André-Barrès, C.; Vial, H. New amino endoperoxides belonging to the antimalarial G-factors series. Eur. J. Org. Chem., 2007, 19, 3095-3101.

[62] Bernat, V.; André-Barrès, C.; Baltas, M.; Saffon, N.; Vial, H. Synthesis of antimalarial G-factors endoperoxides: relevant evidence of the formation of a biradical during the autoxidation step. Tetrahedron, 2008, 64, 9216-9224.

[63] S. Hindley, S. A. Ward, R. C. Storr, N. L. Searle, P. G. Bray, B. K. Park, J. Davies, P. M. O’Neill, Mechanism-based design of parasitetargeted artemisinin derivatives: Synthesis and antimalarial activity of new diamine containing analogues. J. Med. Chem., 2002, 45, 10521063.

[64] Bernat, V.; Saffon, N.; Maynadier, M.; Vial, H.; André-Barrès, C. $\alpha$-Spiro endoperoxides: synthesis and evaluation of their antimalarial activities. Tetrahedron, 2009, 65, 7372-7379.

[65] Maether, M.-P.; Desoubzdanne, D.; Izquierdo, A.; Guieu, V.; Maturano, M.; André-Barrès, C.; Valentin, A.; Jullian, V.; Chevalley, S.; Maynadier, M.; Vial, H.; Payrastre, C. Synthesis and Antimalarial Properties of Streptocyanine Dyes. ChemMedChem, 2009, 4, $1327-1332$.

[66] Maether, M.-P.; Bernat, V.; Maturano, M.; André-Barrès, C.; Ladeira, S.; Valentin, A.; Vial, H.; Payrastre, C. Synthesis and antiplasmodial activity of streptocyanine/peroxide and streptocyanine/4-aminoquinoline hybrid dyes. Org. Biomol. Chem., 2011, 9, 74007410 .

[67] Krishna, S.; Davis, T.M.E.; Chan, P.C.Y.; Wells, R.A.; Robson K.J.H. Ciprofloxacin and Malaria, The Lancet, 1988, 331, 1231-1232.

[68] Dubar, F. ; Anquetin, G.; Pradines, B.; Dive, D.; Khalife, J.; Biot, C. Enhancement of the Antimalarial Activity of Ciprofloxacin using a Double Prodrug/Bioorganometallic Approach. J. Med. Chem., 2009, 52, 7954-7957.

[69] McFadden, G.I.; Reith, M.; Munholland, J.; Lang-Hunnasch, N. Plastid in human parasites. Nature, 1996, 381, $482-482$.

[70] PhD Bernat, V.; Université de Toulouse, 2008, France.

[71] Dubar, F.; Wintjens, R.; Martins-Duarte, E. S.; Vommaro, R. C.; de Souza, W.; Dive, D.; Pierrot, C.; Pradines, B.; Wohlkonig, A.; Khalife, J.; Biot, C. Ester prodrugs of ciprofloxacin as DNA-gyrase inhibitors: synthesis, antiparasitic evaluation and docking studies. MedChemComm, 2011, 2, 430-435.

[72] Nilsen, A.; LaCrue, A.N.; White, K.L.; Forquer, I.P.; Cross, R.M.; Marfurt, J.; Mather, M.W.; Delves, M.J.; Shackleford, D.M.; Saenz, F.E.; Morrisey, J.M.; Steuten, J.; Mutka, T.; Li, Y.; Wirjanata, G.; Ryan, E.; Duffy, S.; Kelly, J.X.; Sebayang, B.F.; Zeeman, A-M.; Noviyanti, R.; Sinden, R.E.; Kocken, C.H.M.; Price, R.N.; Avery, V.M.; Angulo-Barturen, I.; Jiménez-Díaz, M.B.; Ferrer, S.; Herreros, E.; Sanz, L.M.; Gamo, F-J.; Bathurst, I.; Burrows, J.N.; Siegl, P.; Guy, R.K.; Winter, R.W.; Vaidya, A.B.; Charman, S.A.; Kyle, D.E.; Manetsch, R.; and Michael K. Riscoe, M.K. Quinolone-3-Diarylethers: A New Class of Antimalarial Drug. Science Translational Medicine, 2013, 5(177), 177ra37. 